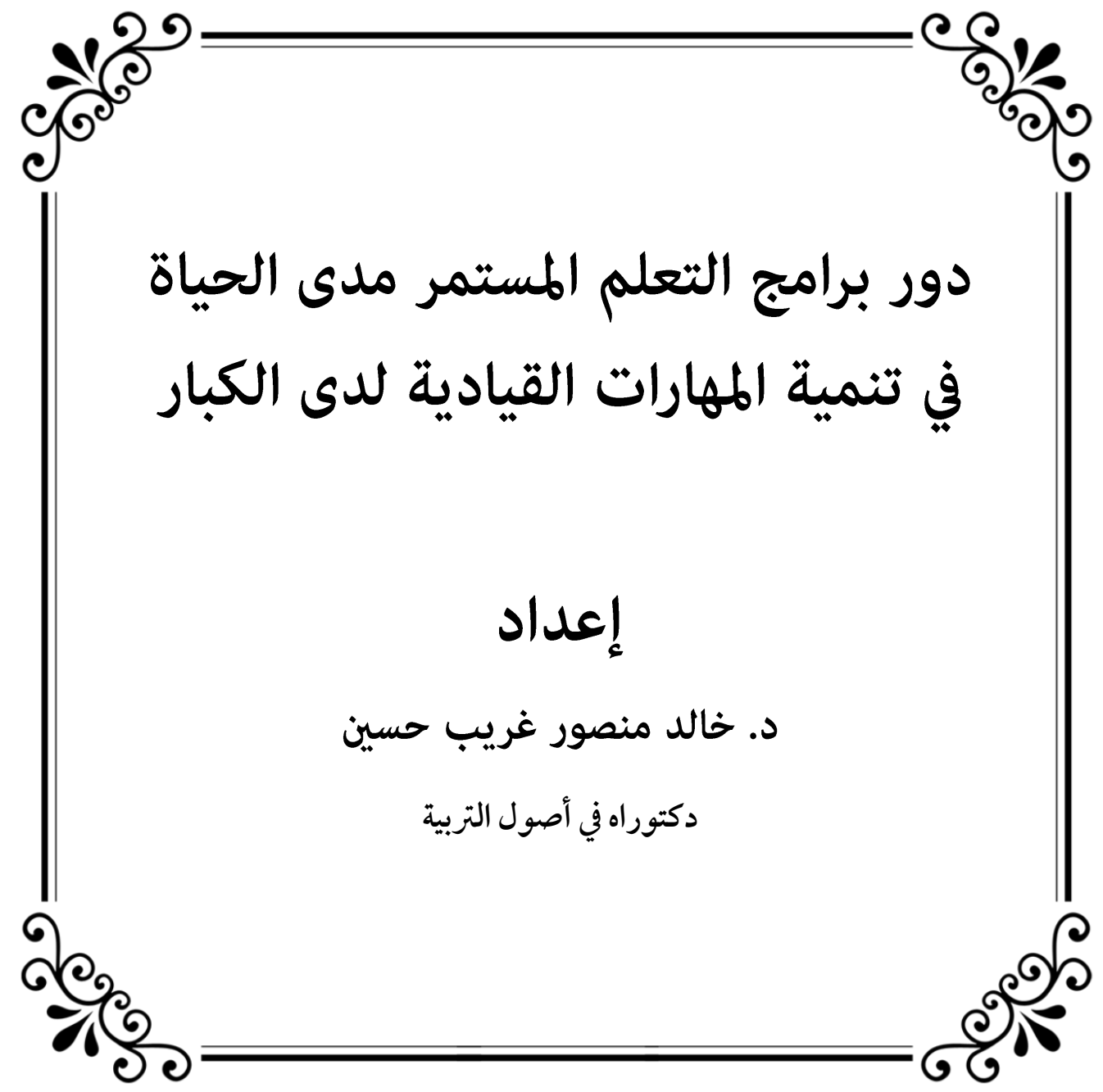





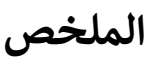

هدفت الدراسة إلى التعرف على واقع تنمية المهارات القيادية لدي الكبار ببرامج التعلم

المستمر مدي الحياة، والكشف عن أهم احتياجات الكبار من المهارات القيادية؛ وتقديم تصور

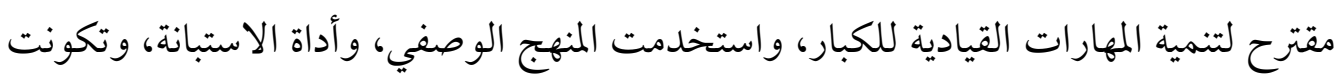

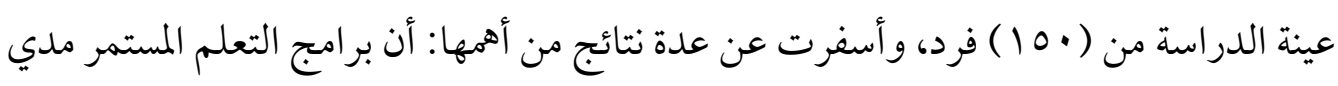

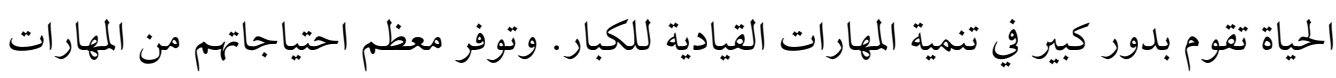

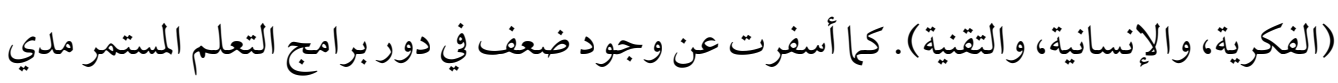

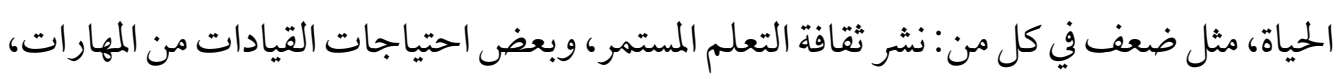

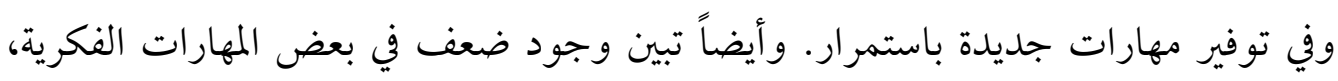

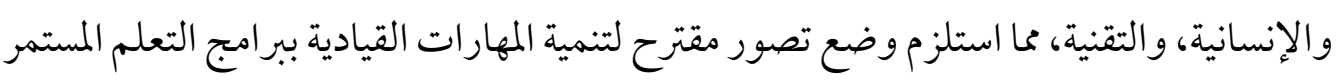
مدي الحياة للكبار. الكلمات لمفتاحية: الدور ـ التعلم المستمر مدي الحياة ـ القيادة ـ الكبير.

\section{The summary:}

This study aimed to know the reality of the development in leader ship skills of adult in the continuous life long learning program, also to detect the needs of adult of leader ship skills and to represent a suggestion to develop the of leader ship skills for adult. I used the descriptive method, the questionnaire consisted of 150 persons and the most important results are: The continuous life long learning program has a great role in developing the leader ship skills for adults, make the needs of the skills available (the Intellectual, technical and humanity) the study also showed the weakness of the role of continuous life long learning programs and spreading of the culture of The continuous life long learning some of the leadership skills, giving new skills and showed a weakness in the Intellectual, technical and humanity skills so there was a must to give a suggest to develop the leader ship skills in the continuous life long learning programs for adult. 


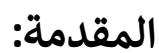

إن اهداف التعلم المستمر مدى الحياة تغيرت وفقاً للبلدان من كونها مطلباً إنسانياً على اعتبار أن التعليم حق تسلم به جميع الأديان والأعراف كونها منهجاً اقتصادياً لما له دور كبير في توسيع النمو الاقتصادي والتطور الصناعي والتكنولوجي لهذه البلدان. ومنذ بدء بر امج التعلم مدى الحياة خلال ثحانينيات القرن الماضي أدرك المخططون وصانعو السياسات التربوية ضرورة تناول هذا الموضوع بالتحليل والنقاش بوصفه أداة مهمة لمواكبة التحيات والمتغيرات المستمرة و التي منها ظهور ثورة تكنولوجيا المعلومات و الاتصالات.

ومع التسارع الهائل للمعرفة وتكنولوجياتها، تقل قيمة المهارات و المعارف التي يمتلكها الأفراد بسرعة. لذا لم يعد توقف الإنسان عند مرحلة من مراحل التعلم مفيداً ومقبولاً نظرا للمدخلات الجديدة التي قدمتها وروجت لها ونشرتها الثورة التكنولوجية، وكان لزاما عليه أن يساير هذه التطورات عن طريق تحديث المهارات التي يمتلكها من حلال التعلم المستمر مدى الحياة، وبالتالي يستطيع الفرد التنافس في الاقتصاد العالمي، بل ويتمكن من العيش والحياة في هذا (1). العصر سريع التغير. وأصبح نمو وتقدم المجتمعات إنسانياً وحضارياً وتكنولوجياً ومهنياً - بمنظ|ته ومؤسساته ومرافقه المختلفة مرتبط إلى حد كبير بفاعلية قياداتها وإدارييها، فالقرارات التي يصنعونها تشكل الفرق الأساس بين النجاح والفشل، وبين النمو والجمود، وبين التقدم والتأخر. فالقادة الإداريون الفاعلون هم الذين يمتلكون اليد الطولي المؤثرة في صنع القرارات في مؤسساتهم ومنظلتهم بمختلف أنو اعها، وهم بالتالي يلعبون دوراً أساسياً وخطراً في تحديد أهدافها، وتوجيه مسار اتها وسبل تحقيق أهدافها. إنه لمن الأهمية بمكان تطوير وعيهم بالدور النشط الذي يحارسه القادة الإداريون في حياة المنظات الإنسانية. 
كما أننا نعيش اليوم ضمن محيط متغير باستمرار يجعل القيادة الفعالة أكثر صعوبة من أي وقت مضي في كل مظهر من مظاهر الحياة المستقلة والتبادلية. نحن بحاجة ماسة لرؤية جديدة

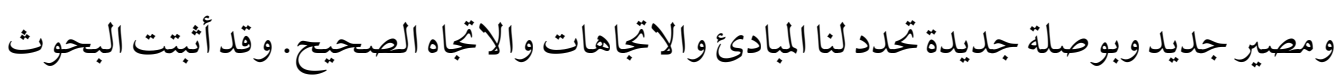

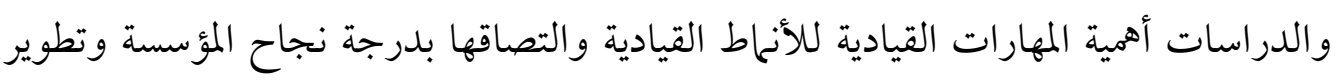

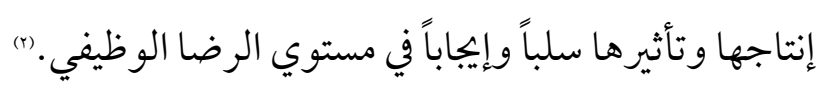

\section{مشكلة الدراسة:}

تشير العديد من الدراسات في مجال البحث الإداري والتربوي إلي ضرورة الاهتمام

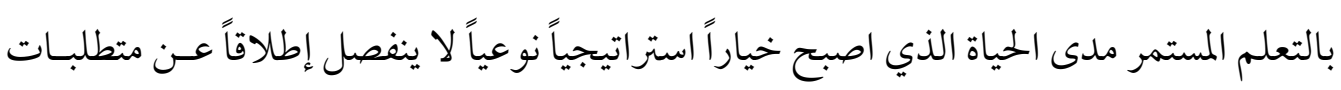

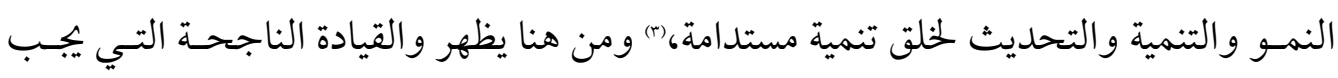
أن تتمتع بالمهارات الازمة لتقود الأفرادو المنظطات بنجاح، ومما يؤكد ذلك ما يلي: تأكيد أحدي الدراسات على أن التعلم المستمر مدي الحياة يمثل "علامة أمان" للفرد

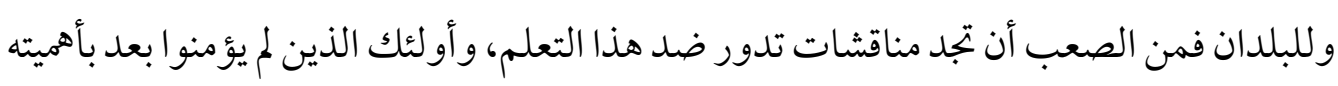

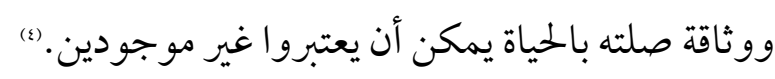

هناك تأكيد على أن التعليم النظامي بكافة مر احله مازال يعاني من بعض السلبيات مثل: ضعف مراعاة المناهج للفروق الفردية بين الطلاب، وقلة الوسائل التي تساعد على تنمية مهارات

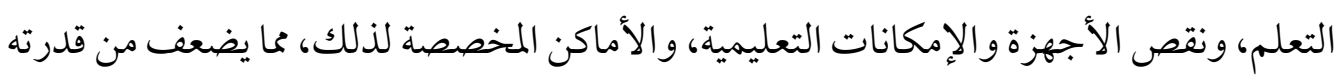
على المنافسة داخلياً وخار جياً. تدني مستوي التعليم وتخريج نوعية من الطلاب لا تو اكب متطلبات العصر الحالي، وأيضا انخفاض مستوي التدريب، وبخاصة بالمؤسسات الحكومية. (1) 
تأكد أحدي الدراسات على أن والتغيرات المستمرة تعمل تلقائياً على خفض الطلب على العمالة غير الماهرة، ويزيد من الطلب على العمالة الماهرة التي تمتلك مهارات العمل. (N)

وبعبارة أخري يمكن القول إن التغير المستمر في متطلبات سوق العمل المتغيرة يفرض

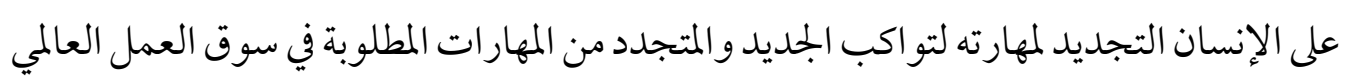
الواسع والمحلي المتناثر . المبان التعلم في السنوات المبكرة من حياة الفرد، لم يعد كاف لتوفير حياة كريمة على مدي حياته،

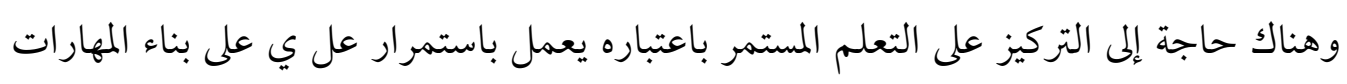

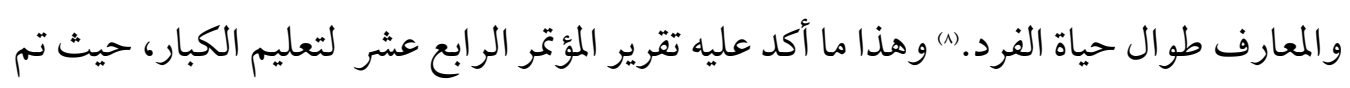
توجيه دعوة للباحثين للاهتمام بالتعلم المستمر لتحقيق التنمية..(1)

هناك تأكيد على أن إيجاد القيادة الإدارية السليمة، والقادرة على مواجهة المستجدات

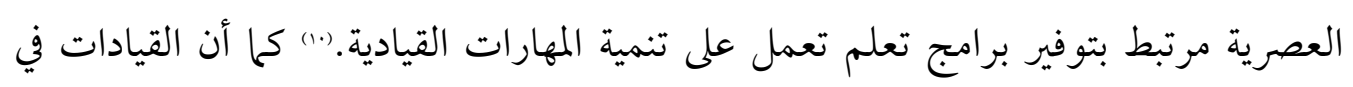

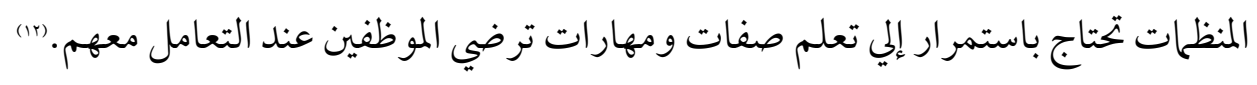
إن القيادة والتأثير على التابعين داخل المنظمة هما وجهان لعمله واحدة تسير في اتجاه

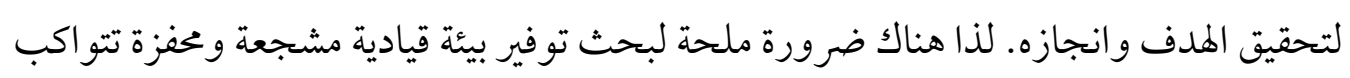
مع المتغيرات المستمرة. تتعدد وتتنوع تحديات القرن الحادي والعشرين من كوارث طبيعية وأزمات تنظيمية

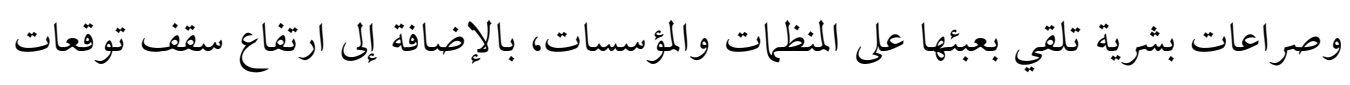
المستفيدين من الخدمات المقدمة من هذه المؤسسات كل هذا يستدعي تطوير القيادات وتنميتها

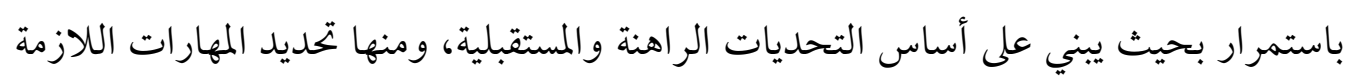

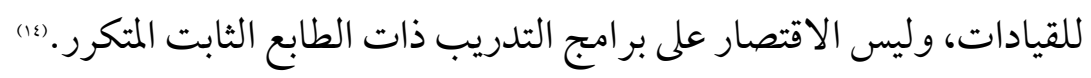


وعليه يمكن تحديد مشكلة الدراسة في السؤال الرئيس التالي: ما دور برامج التعلم

المستمر مدي الحياة في تنمية المهارات القيادية لدي الكبار؟ ويتفرع من هذا السؤال الأسئلة التالية: ا ـ ماهية التعلم المستمر مدي الحياة واسسه ومبادئه؟ r ـ ما أهم احتياجات الكبار من المهار ات القيادية؟

بـ ما واقع تنمية المهارات القيادية لدي الكبار ببرامج التعلم المستمر مدي الحياة؟ عـ ما التصور المقترح لتنمية المهارات القيادية ببرامج التعلم المستمر مدي الحياة للكبار؟ أهداف الدراسة: ا ـ التعرف على ماهية التعلم المستمر مدي الحياة واسسه ومبادئه. r- إبراز أهم احتياجات الكبار من المهارات القيادية. بـ الكشف عن واقع تنمية المهارات القيادية لدي الكبار ببرامج التعلم المستمر مدي الحياة. ع_وضع تصور مقترح لتنمية المهارات القيادية ببرامج التعلم المستمر مدي الحياة للكبار.

\section{أهمية الدراسة:}

تكمن أهمية هذه الدراسة في النقاط التالية:

اـ أهمية التعلم المستمر مدي الحياة، والمهارات القيادية حيث أكدت العديــ مـن التقاريـر

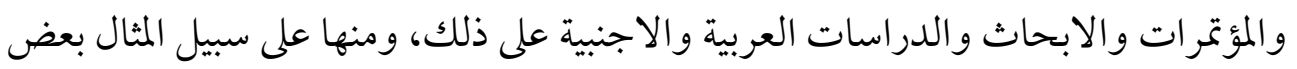
التقارير الصادرة عن البنك الدولي. r ـ توفير القيادات اللازمة بها تستلزمه من مهار ات عقلية وعملية. بـ إبراز أهمية التعلم المستمر مدي الحياة، وتأكيد مسؤوليته في تنمية المهارات القيادية للكبار؛ من أجل النهوض بالأفر اد و المؤسسات و المجتمع. 
ع- يمكن أن تفيد المسئولين عن برامج التعلم المستمر مدي الحياة المقدمة للكبار وخططي السياسات في وضع قـرارات صحيحة ومفيدة؛ فيما يتعلق ببرامج التعلم المستمر مدي الحياة الخاصة بتنمية المهارات القيادية للكبار.

هـ أهمية الدور القيادي للكبار، وتأثيره على أداء المؤسسات واستمرار نجاحها، في ظل التحديات و التغيرات المتلاحقة والمستمرة.

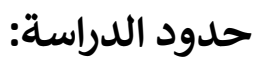

ستركز الدراسة على مرحلة التعلم المستمر مدى الحياة بداية من عمر (Y0) وهي مرحلة التعليم غير الاجبارية، والتي تعتبر امتداداً للمراحل السابقة من التعليم النظامي، وايضا لأنها بداية العمل وتولي قيادة كل من الفرق والاقسام والإدارات و المؤسسات والشركات...إلخ من منصاب قيادية، ولن تحدد الدراسة حد اقصي للعمر على اساس أن البعض يتولى القيادة ويكون في مرحلة متأخرة من العمر. و اعتمدت الدراسة الميدانية على عينة من بعض قيادات المؤسسات الحكومية والخاصة، وبعض مديري كل من: إدارة الموارد البشرية، ومراكز التدريب ببعض المؤسسات الحكومية والخاصة؛ بهدف التعرف على واقع تنمية المهارات القيادية لدي الكبار ببرامج التعلم المستمر مدي الحياة.

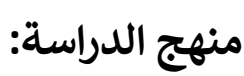

اعتمدت الدراسة الحالية على (المنهج الوصفي) بأدواته المختلفة، لوصف واقع برامج التعلم المستمر مدي الحياة في تنمية المهارات القيادية لدي الكبار بمصر، وتجميع البيانات اللازمة وتنظيمها وتحليلها بدقة؛ بهدفة الوصول إلى النتائج المنشودة. 


\section{أداة الدراسة:}

استبانة موجه لبعض قيادات المؤسسات الحكومية والخاصة، وبعض مديري كل من:

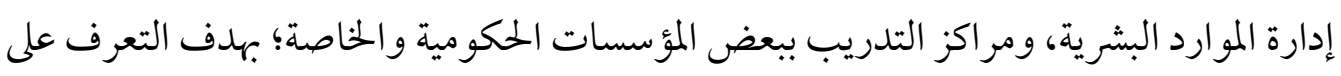
واقع تنمية المهارات القيادية لدي الكبار ببرامج التعلم المستمر مدي الحياة.

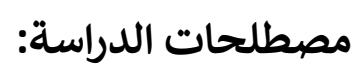

الدور:

يعرف الدور بأنه "بجموعة الوظائف والمهام المنصوص عليها بالقانون أو اللائحة والتي

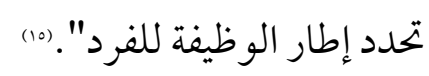

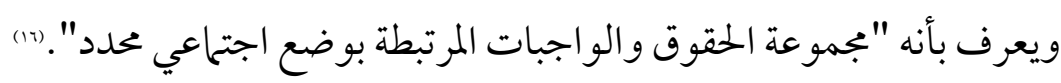

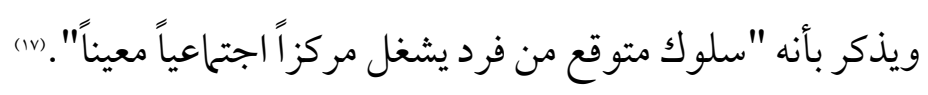

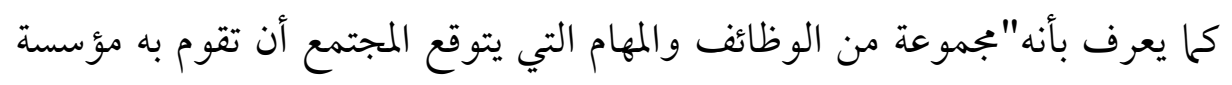

$$
\text { (11). معينة }
$$

ومن ثم يمكن تعريف الدور إجرائيا بهذه الدراسة على أنه "المهام والمسئوليات والخططط

المناط ببرامج التعلم المستمر مدي الحياة القيام بها لتنمية المهارات القيادية لدي الكبار في ضوره

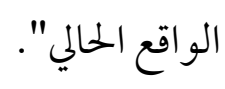

\section{التعلم المستمر مدي الحياة:}

يعرف التعلم المستمر مدي الحياة وفقاً لقاموس هاربر كولينز (Harper Collins) بأنه "استخدام كل فرص التعلم الرسمية وغير الرسمة طوال فترة حياة الأفراد؛ من أجل تعزيز

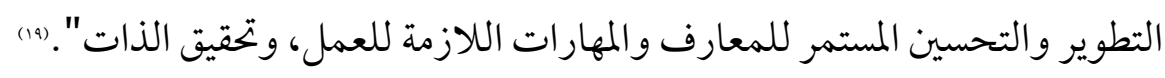


ويذكر التعلم المستمر مدي الحياة بأنه "إتاحة فرص تعليمية مستمرة طوال حياة الأفراد؛ وذلك بقصد تنمية أفر اد المجتمع وتطويرهم؛ ليتمكنو ا من تحقيق التكيف مع المتطلبات الحضارية،

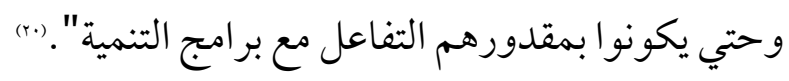

كما يعرف التعلم المستمر مدي الحياة بأنه "جهد اجتماعي لاكتساب المعرفة واستخدامها في حياة أفضل للجميع وهي تنطلق من إدراك طاقة وقدرات كل إنسان وجماعة فتحاول تمكينهم

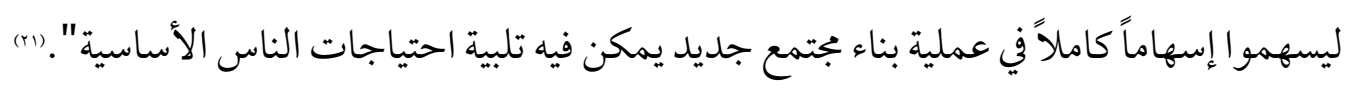
ويذكر بأنه "قدرة الإنسان على التعلم مدي حياته دون تقيده في زمان تعلمه ومكانه،

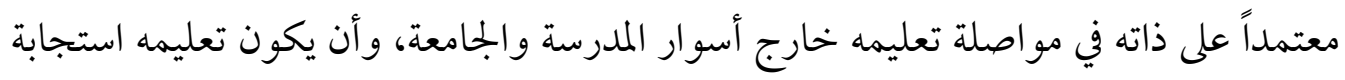

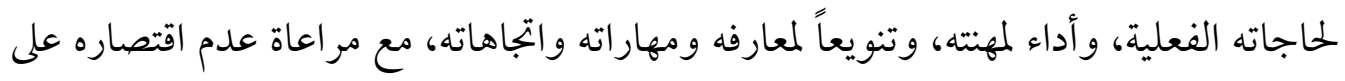
تعليم الكبار، بل يشمل مر احل التعليم، من عام وعال، ونظامي أو غير نظام". ومن ثم يمكن تعريف التعلم المستمر مدي الحياة إجرائيا بهذه الدراسة على أنه "إتاحة برامج تعلم مستمر مدي الحياة للكبار بعد انتهائهم من مرحلة التعليم الاجبارية، لتنميتهم وتطويرهم؛ بهدف تحسين كفاءتهم، وزيادة قدراتهم الذاتية، واكتسابهم معارف ومهارات

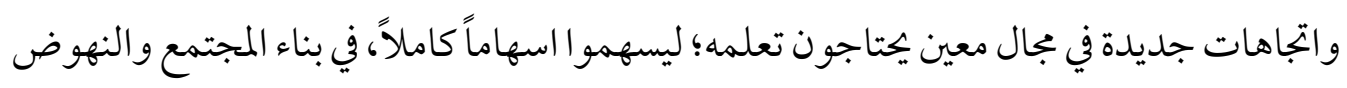
بالأفر ادو المؤسسات، والتنمية الشاملة، حاضراً ومستقبلاً.

\section{القيادة:}

التعريف اللغوي للقيادة "المعني الاشتقاقي للقيادة يعود جذورها للفكر القديم لكلمة

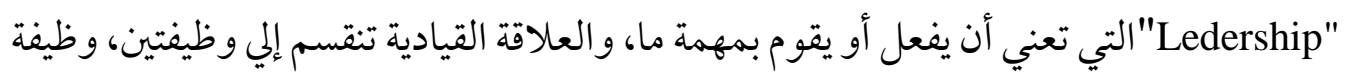
إعطاء الأوامر وهي من حق القائد، ووظيفة تنقيذ الأوامر وهي واجبة على الأتباع". 
أما في اللغة العربية "كلمة القيادة نابعة من فعل القود وهي عكس السوق، فالقيادة من الأمام والسوق يكون في الخلف، والانقياد هو الخضوع، يقال انقاد لي أي أعطاك مقادته ويقال

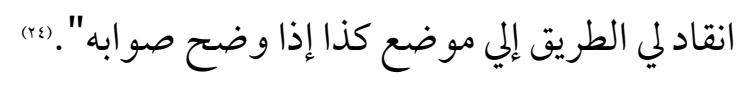

وعند تعريف القيادة اصطلاحاً نجد أن هناك العديد من المفاهيم وتم تناول أهمها كالتالي: تعرف القيادة بأنها "التي تنسق بين جهود المرؤوسين وتحثهم على العمل وتدفعهم إليه عن اقتناع ورغبة في سبيل تحقيق أهداف المنظمة وأهدافهم بشكل متكامل وناجح". وتعرف بأها "السعي من أجل الوصول إلي تحقيق الأهداف المشتركة من خلال ممارسة

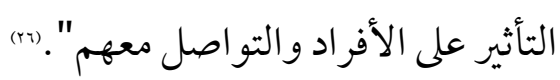
ويذكر بأنها "العملية التي تحمل في جوهر ها كامل مخزون الفر الفرد المعرفي والعقائدي والتي

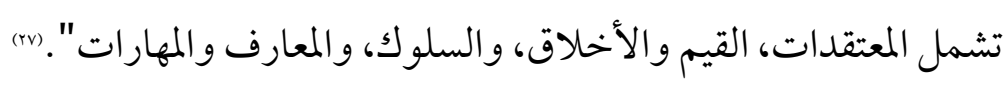

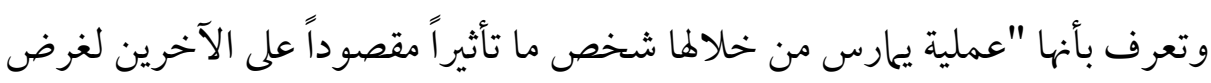

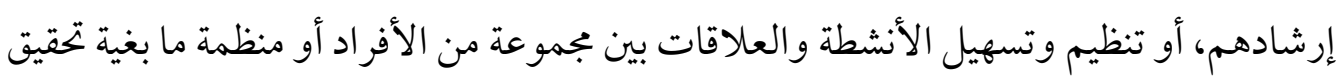
أهداف المنظمة بكفاءة عالية". ويذكر بأنها "عملية التأثير على الآخرين للوصول إلي فهم واتفاق مشترك حول الأعمال

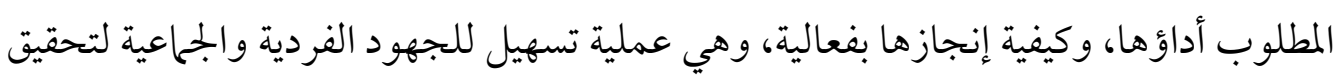
أهداف مشتركة". (ه) ومن ثم يمكن تعريف القيادة إجرائيا بهذه الدراسة على أنها "عملية يوظف من خلالها شخص ما مهارته للتأثير المقصود على الآخرين بغرض إرشادهم، أو تنظيم وتسهيل الأنشطة

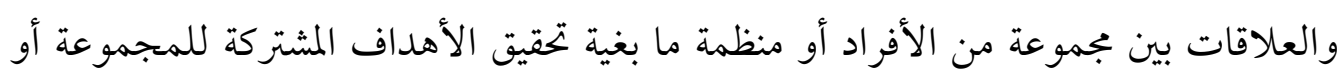
المنظمة بكفاءة عالية. 


\section{الكبير:}

من ناحية الأصول اللغوية اشتقت كلمة الكبير (adult) بالإنجليزية من الفعل اللاتيني (adolescere) وصل إلى سن النضج ولم يعد قادراً على مزيد من النمو و التطور (·) ويوجد ثلاث معاير لتحديد من هو الكبير وهي كالتالي:(r)

العمر: يستند البعض إلي العمر البيولوجي لتحديد من هو الكبير بمعني أحقية الفرد في الحصول على بطاقة شخصية أو هوية، أو الإدلاء بصوته في الانتخابات، أو من مرحلة التعليم الأساسي. وعلى الرغم من أهمية هذا المعيار ووجاهته إلا أنه يعبر عن مدي قدرة الشخص على القيام بمهام الكبار. النضج النفسي: يعتبر هذا المعيار أكثر دقة من المعير السابق، ولكن السؤال الذي يطرح نفسه كيف يمكن الحكم على شخص ما أنه قد نضج نفسياً؟ و ما المرحلة التي يتحول عندها الفرد إلى شخص كبير؟ كما أن قضية النضج النفيي جدلية بطبيعتها حيث تختلف الآراء حولها. الدور الاجتهاعي: ينطلق هذا المعيار من أن المسؤوليات التي يتحملها الفرد في كل مرحلة من مراحل العمر تكون لما طبيعة خاصة، فالمسؤوليات التي يتحملها الطفل الصغير غالبا ما تكون محددة على العكس من ذلك مسؤوليات الكبير فهي متنوعة ومتعددة مثل دوره كزوج، وولي أمر غيره، ودوره كقائم بنشاط إنتاجي،...إلخ. ويعرف الكبير بأنه "الشخص الذي يدخل مرحلة من الحياة يتحمل فيها مسؤوليات

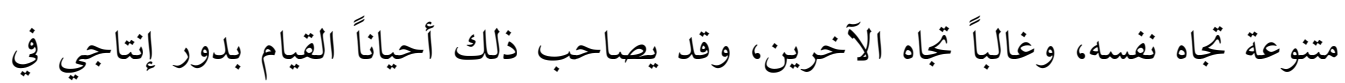

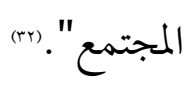

ومن ثم يمكن تعريف الكبير إجرائيا بهذه الدراسة على أنه "الشخص الذي انتهي من التعليم النظامي، ووصل إلى مرحلة عمرية معينة، يتحمل فيها مسؤوليات متنوعة تجاه نفسه والآخرين، ويقوم بدور إنتاجي في المجتمع. 


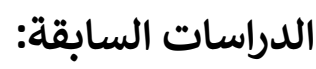

انطلقت هذه الدراسة من خلال الاعتماد على العديد من الدارسات، المرتبطة بمجال الدراسة الحالية سواء في ججال التعلم المستمر مدي الحياة أو في ججال القيادة، وسوف يتم عرض أهم

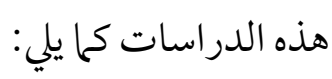

\section{أولاً: دراسات سابقة تناولت التعلم المستمر مدي الحياة: وتتمثل فيما يلي:

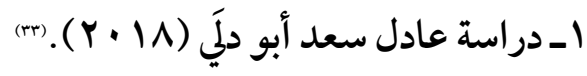

هدفت الدراسة إلى التعرف على تأثير مفهوم بجتمع المعرفة وخصائصه في التعلم المستمر، وكفايات التعلم المستمر ومتطلبات تحقيقها في ججتمع المعرفة، واستخدمت المنهج الوصفي. وأداة الاستبانة. وأسفرت عن عدة نتائج من أهمها: أن التعلم المستمر في بجتمع المعرفة، مطالب بإحداث تغيرات على أربعة مستويات: مفهومه وأهدافه، ومحتو اه، وطرقه، وإدارته، وأن درجة أهمية كل من كفايات التعلم المستمر ومتطلبات تحقيقها في مجتمع المعرفة عالية جداً. وتتفق هذه الدراسة مع الدراسة الحالية في تركيزها على التعلم المستمر، واستخدامها للمنهج الوصفي. بينما تختلف في كل من عينة وبجتمع ويعض أهداف الدراسة. وأمكن الاستفادة من خلال الإطار النظري، ويعض نتائج ومقترحات هذه الدراسة.

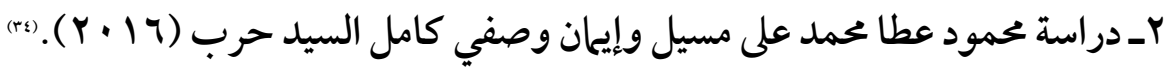
هدفت الدراسة إلى وضع تصور مقترح لتصميم مؤشر التعلم المركب لقياس التعلم مدي الحياة في مصر، في ضوء خبرة كندا في هذا المجال. واستخدمت المنهج الوصفي التحليلي. وأسفرت عن عدة نتائج من أهمها: استطاعت كندا من خلال مؤشر التعلم المركب أن تطور من ججال التعلم مدي الحياة بها؛ مما ساعد على تحقيق حياة أفضل للكنديين، ورفع المستوي الاقتصادي، وإحداث روابط قوية بين المجتمعات الكندية، وتحفيز الحوار الوطني عن أهمية التعلم المستمر مدي الحياة، 
وطرقه. وتتفق هذه الدراسة مع الدراسة الحالية في تركيزها على التعلم المستمر مدي الحياة،

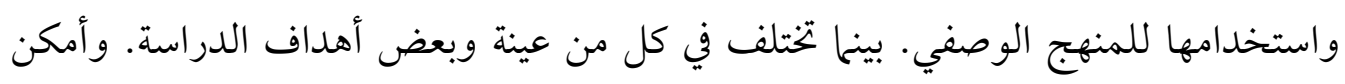
الاستفادة من هذه الدراسة من خلال الإطار النظري، وبعض النتائج، وبناء التصور المقترح.

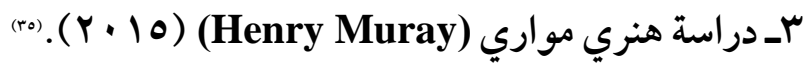
هدفت الدراسة إلى بحث العلاقة بين التعلم الذاتي ونواتج التعلم مدي الحياة، ومدي

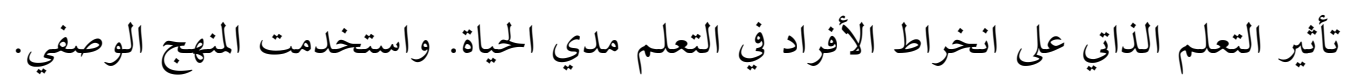

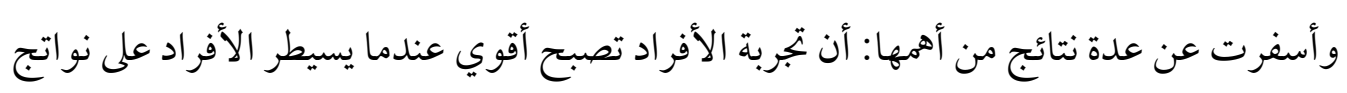

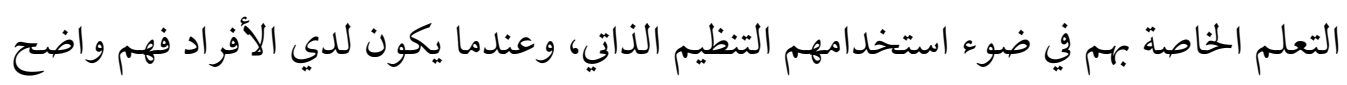
لمفهوم التعلم الذاتي، فإن ذلك يعمل على تطوير قدرات الأفراد وتمكينه من الاختيار من بين

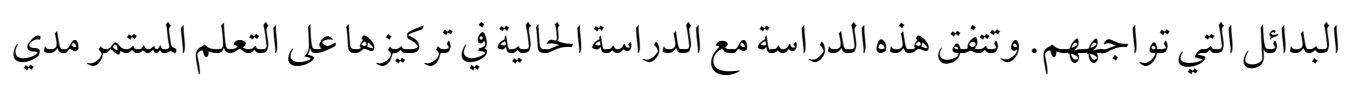

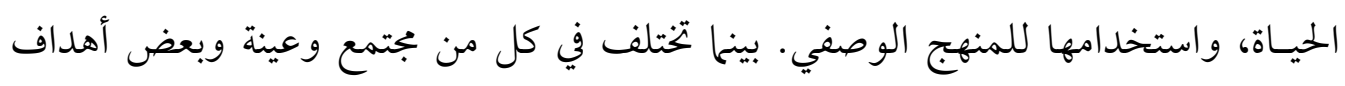
الدراسة. وأمكن الاستفادة من هذه الدراسة من خلال الإطار النظري، وبعض الهن النتائج.

ثانياً: دراسات سابقة تناولت القيادة: وتتمثل فيما يلي:

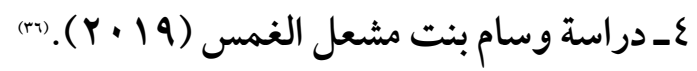
هدفت الدراسة إلى التعرف على دور القيادة التحويلية في تحقيق التميز المؤسسي في

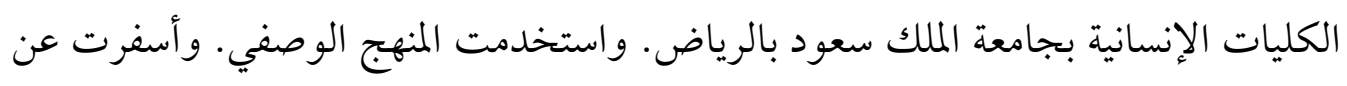

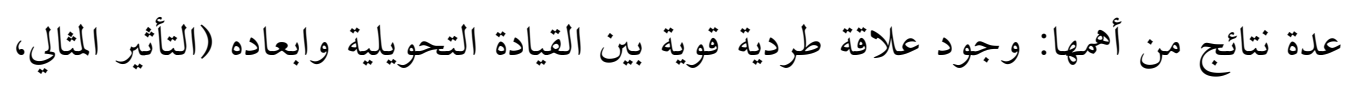
التحفيز، الاستثارة الفكرية، الاعتبارات الفردية) والتميز القيادي، والتميز البشري، التميز الخدماتي. وتتفق هذه الدراسة مع الدراسة الحالية في تركيزها على بعض المهارات القيادية، بينما 
تختلف في كل من عينة ومجتمع وبعض أهداف الدراسة. وأمكن الاستفادة من هذه الدراسة من خلال الإطار النظري، وبعض النتائج.

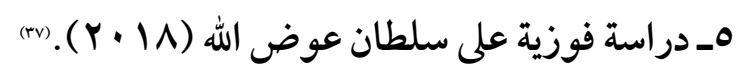
هدفت الدراسة إلى التعرف على واقع القيادة الإبداعية باستخدام إدارة الأزمات والإدارة بالأهداف في منظمات الجامعة العمالية ومعرفة العلاقة بين القيادة الإبداعية وإدارة الازمات وإدارة الأهداف. وأسفرت عن عدة نتائج من أهمها: أن ممارسة القيادة الإبداعية داخل الجامعة العمالية

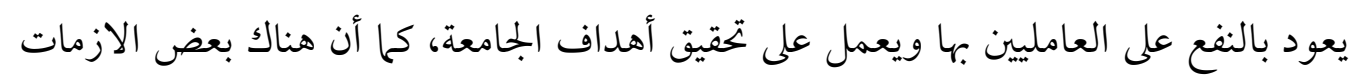

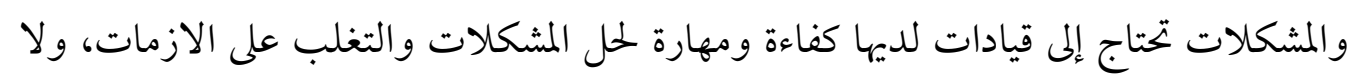
يمكن حلها أو التعامل معها بالطرق التقليدية. وتتفق هذه الدراسة مع الدراسة الحالية في تركيزها على بعض المهارات القيادية، بينما تختلف في كل من عينة وبعض أهداف الدراسة. وأمكن الاستفادة من هذه الدراسة من خلال الإطار النظري، وبعض النتائج، وبناء التصور المقترح.

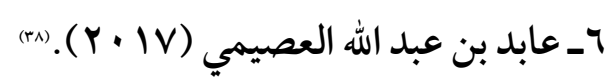

هدفت الدراسة إلى توضيح مفهوم القيادة الإدارية ومفهوم تطوير القائد الإداري. كما تهدف إلى تقديم نموذج مقترح لاستراتيجية تطوير القيادة الإدارية في المنظمات الحكوميـــــة.

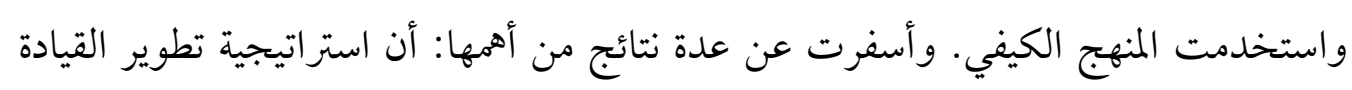

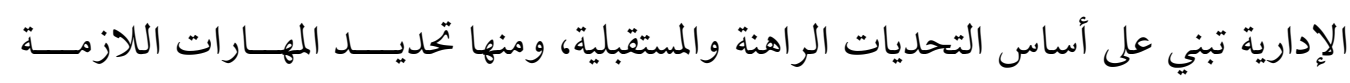
للقيادات الإدارية، وليس الاقتصار على برامج تدريب الموارد البشرية ذات الطابع الثابت المتكرر.

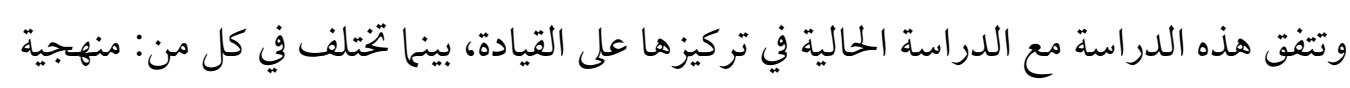

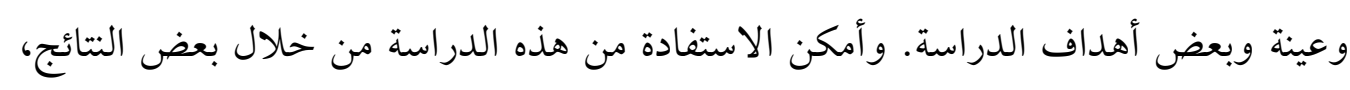
و التوصيات. 


\section{الإطار النظري للدراسة:

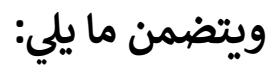
المحور الأول: ماهية التعلم المستمر مدي الحياة وأهدافه واسسه ومبادئه: أولاً: ماهية التعلم المستمر مدي الأول: ماهية التعلم المستمر مدي ثانياً: أهدافه التعلم المستمر مدي الحياة. ثالثاً: اسس ومبادئ لتعلم المستمر مدي الحياة. المحور الثاني: المهارات القيادية واحتياجات الكبار منها:

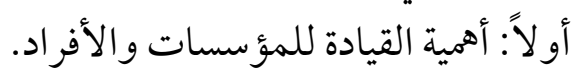
ثانياً: تأثير مهارات القيادات على نجاح المؤسسات. ثالثاً: سمات وصفات القائد الفعال. رابعاً: أهم احتياجات الكبار من المهارات القيادية.

المحور الثالث: الواقع الراهن لتنمية المهارات القيادية لدي الكبار ببرامج التعلم المستمر مدي الحياة (الدراسة الميدانية). أولاً: إجراءاء الدراسة الميدانية. الدراسة الميدانية. ثانياً: نتائج الدراسة الميدانية وتفسيرها. المحور الرابع: تصور مقترح لتنمية المهارات القيادية ببرامج التعلم المستمر مدي الحياة للكبار. وتم تناولهم كما يلي: المحور الأول: ماهية التعلم المستمر مدي الحياة وأهدافه واسسه ومبادئه:

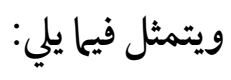

اولاً: ماهية التعلم المستمر مدي الحياة. بداية ظهور مصطلح التعلم المستمر مدي الحياة كانت عام 9 بو ام، حيث تم تداول المصطلح في المملكة المتحدة على يد باسل ياسكل (Basil Yeaxlee) وكان ياسكل عضواً نشطاً في لجنة تعليم الكبار، وسكرتير عام الرابطة التعليمية آنذاك، إلى جانب محاضراً مدرساً في كلية 
التربية ـ جامعة أكسفورد. ولكن لم يكن المصطلح ذا أهمية إلي ذلك الوقت إلي أن استخدمته منظمة

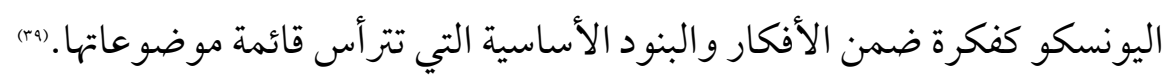

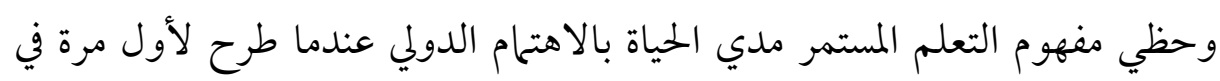

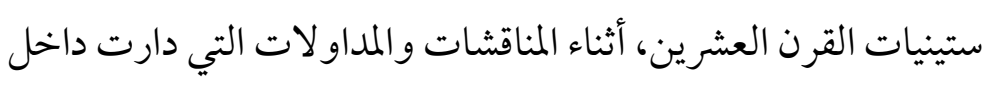

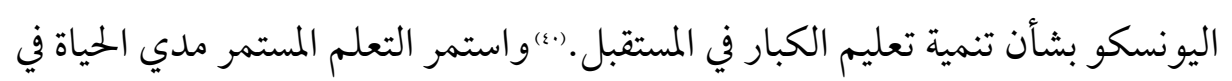

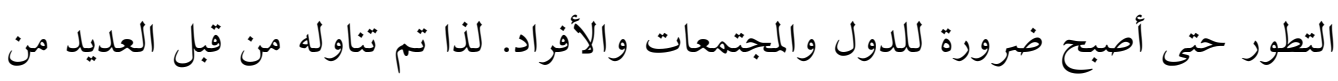
الباحثين بالدر اسة والبحث و التتيجة وجود العديد من التعريفات له ويمكن تناول أهمها فيما يلي: يعرف بأنه "مفهوم يعني استمر ار عملية التعلم دون انقطاع من أجل تحقيق أمال الفرد وتنمية قدراته؛ لتمكينه من مواجهة التغير المستمر "(s).

ويذكر بأنه "المجموع الكلي للعمليات التعليمية المنظمة أيا كان مضمونها أو مستواها أو

أسلو بها وسواء أكانت نظامية أو غير نظامية وسو اء أكانت استمراراً أو بديلاً عن التعلم السابق في لئه

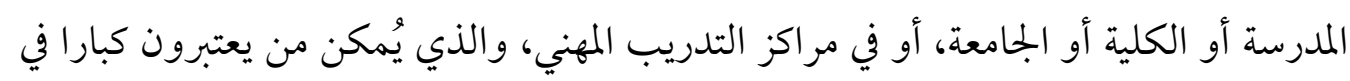
مجتمعهم من تحسين كفاءتهم التقنية والمهنية وزيادة قدراتهم الذاتية وإثراء معارفهم سعياً إلي إكمال أحد مستويات التعلم النظامي واكتساب معارف ومهارات في ميدان جديد وتجديد أو استيفاء

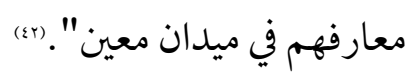
ويعرف بأنه "ذلك التعليم الذي يوفر للفرد فرصا للتعليم واكتساب القدرة على التكيف ميف في

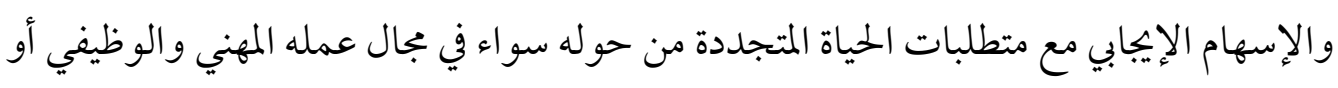
في الاستعمال الذكي للأدوات التكنولوجية من حوله وزيادة فهمه لها أو لمجرد إشباع تطلعه لهنه

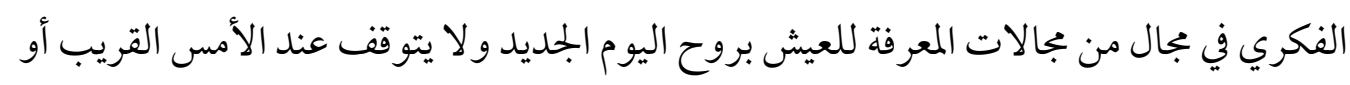
البعيد". (ㅇ) 
ويذكر بأنه "الدراسات الحرة والمنهجية والدورات التدريبة غير المنتهية بمؤهل دراسي،

والتي تقدمها شتي الجهات لمختلف فئات الجمهور بغية تنمية معارفهم واتجاهاتهم ومهار اتهم في

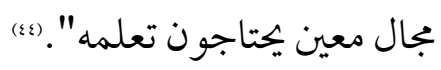

ويعرف بأنه "ذلك التعليم الذي يقدم برامج دراسية معينة لمقابلة احتياجات تعليمية

محددة، ولا ينتهي هذا التعليم بانتهاء الفرد من مرحلة تعليمية محددة، ولا ينتهي هذا التعليم بانتهاء الفرد من مر حلة تعليمية معينة، وإنما يستمر بعد الانتهاء من التعليم المدرسي وتلك البرامج تقدم لبعض الوقت أو لكل الوقت باستمرار الحياة، ومعظم تلك البرامج تعتمد على التعليم الذاتي للفرد.

وقد تم تعريف التعلم المستمر مدي الحياة إجرائيا بمصطلحات تلك الدراسة على أنه

"إتاحة برامج تعلم مستمر مدي الحياة للكبار بعد انتهائهم من مرحلة التعليم النظامية، لتنميتهم

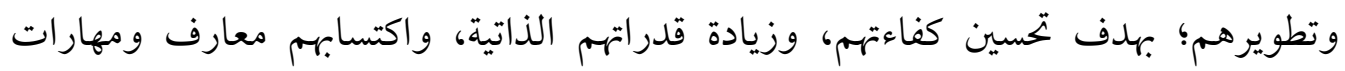

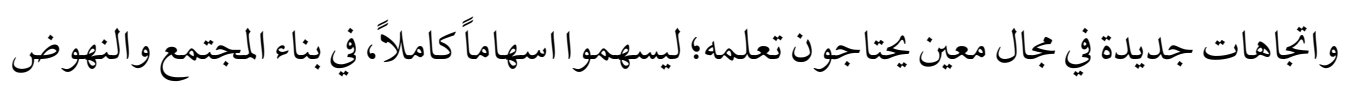
بالأفراد والمؤسسات، وفي التنمية الشاملة، حاضراً ومستقبلاً.

ثانياً: أهداف التعلم المستمر مدي الحياة.

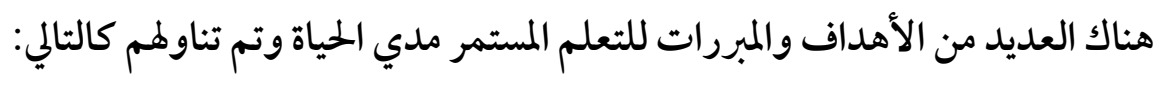
1 ـ أهداف التعلم المستمر مدي الحياة:

إن أهداف التعلم المستمر مدي الحياة لا تعتبر أهداف نهائية، بل هي أهداف تتجدد وتتغير

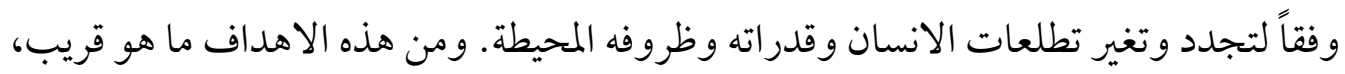
ومنها ما هو بعيد، إلا أن كلها متصلة، وتحقيق الأهداف البعيدة يتطلب تحقيق الأهداف القريبة.

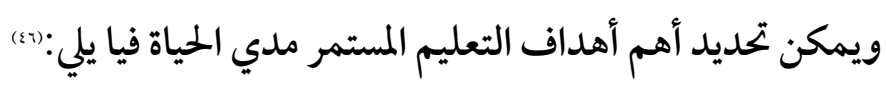


ـ يقدم للأفر اد معلو مات عن كيفية تحسين مهارات القيادة والاتصالات والاتجاهات. ـ يساعد الافراد على اتخاذ القرار الاحسن، وينمي مهار اتهم في حل المشكلات التي تواجهرم في

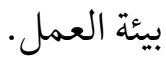
ـ يساعد العاملين في التغلب على حالات القلق والتوتر والاغتراب و الصراع داخل المنظمة. ـ يقلص الهوة الثقافية الناتجة عن اختلاف السرعة بين النمو المادي والنمو المعرفي. ـ يعمل على مو اجهة ما يتتج من مشكلات ناتجة عن التغيير الاجتماعي السريع. ـ يؤدي إلى التوفيق بين القيم والاتجاهات القديمة ومتطلبات العصر الجميد. ـ يعمل على نشر الوعي حول القضايا الكبرى سواء المحلية أو الخارجية. ـ يعمل على أعادة فحص الأفكار وأنحاط السلوك السائدة في المجتمع الحضاري في جوانب الحياة الاجتماعية. - يعمل على التنمية الاقتصادية، وتعزيز موارد دخل المجتمع. - يفتح المجال للفرد نحو الترقية والتقدم الوظيفي. ـ يعمق الاحساس بالرضا الوظيفي والانجاز.

ثالثاً: اسس ومبادئ التعلم المستمر مدي الحياة. يخظى التعلم المستمر مدي الحياة باهتحامات كبيرة على أساس أنمياة أنه عملية تنموية مستمرة للفرد ومجتمعه، وهو تعلم ذو هدف، وتعليم غرضي، يمر به الأفراد طيلة حياتهم. يقوم التعلم مدي الحياة على أساسين: الأول: أساس طبيعي قصدي وغير قصدي. ذلك أن التعلم مدي الحياة تعلم مقصود يتم التخطيط له وتنفيذه في مؤسسات التعليم الرسمي، وهو أيضاً تعلم غير مقصود يتم من خلال برامج تعلم الراشدين. كما يتم من خلال وسائط متنوعة تخطط له، ويخطط الفرد لتعلمه أيضاً، تطويراً لذاته. 


\section{الثاني: أساس أخلاقي، يتفرع إلى أربعة أسس فرعية، وهي:}

ا ـ الالتزام الثخصي بالتعلم: أي يلتزم الفرد أمام نفسه بتعليم نفسه، والتعرض إلى خبرات تصقل إمكاناته وتحقق له المتعة. وهذا الالتزام ينطوي على شعور الفرد بالمسئولية أمام نفسه وأمام بجمعه للتعلم.

Yـ الالتزام الاجتحاعي بالتعلم: وهنا يكون المجتمع ملتزماً بإتاحة فرص التعليم و التعلم لأبنائه، كما أن الأفر اد يشار كون بعضهم البعض خبرات التعلم ويشجع الفرد غيره على التعلم، شعوراً منه بأن تعلم الآخرين يمثل سعادة وفائدة له وفائدة للمجتمع. ــ احترام تعلم الآخرين: أي يحرص المتعلم على مراعاة حقوق غيره في التعلم مدي الحياة تعلماً حرا دون قيود. عـ احترام الحقيقة: والتعلم وفقاً لهذا المبدأ يحترم وجهات نظر الآخرين، متي استندت هذه الآراء رابعاً: مبادئ التعلم المستمر مدي الحياة. الموضوعي والمصدر الموثق. يقوم التعلم المستمر مدي الحياة على بجموعة من المبادئ المترابطة والمتكاملة فيها بينها، ويكون بينها علاقات تجعلها أشبه بالمنظومة، ويمكن تحديد أهم هذه المبادئ فيما يلي:(يء) الشمول: وهذا يعني أنها تشمل جميع مراحل الانسان من المهد إلى اللحد، وجميع أنواع التعلم الرسمية وغير الرسمية. التكامل: تكامل التعلم مع مختلف المؤسسات التعليمية ابتداء من المنزل والمدرسة وجميع مناشط الحياة الآخرين للأفر اد في المجتمع. لذا لا يجب النظر إلى التعلم على انه مستقل عن العمل الذي يهارسه الإنسان في المجتمع، فالمجتمع المتعلم يؤكد على التعلم مدي الحياة. الاستمرارية: يؤكد التعلم مدي الحياة على استمرارية عملية التعلم مدي الحياة للفرد، بها يتيح تحقيق تقدم نوعي في حياة الفرد الشخصية والاجتماعية والمهنية، حيث يجب علية الاطلاع على كل ما هو جديد دائما وألا وجد نفسه غير قادر على ملاحقة التطورات المتسارعة من حوله. 
الابتكار: هو استحداث أشكال تعلم بديلة وجديدة وتطوير الأساليب التقليدية لاكتساب التعلم، مع مراعاة مرونة البرنامج التعليمي وأساليب الإدارة والتنظيم.

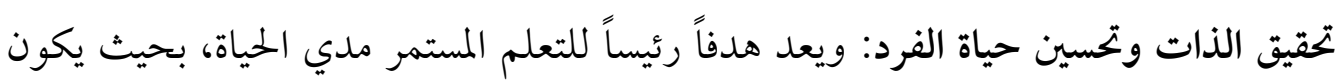

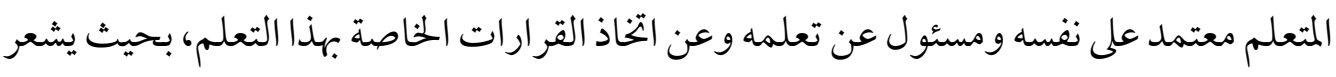
كل فرد بحريته في التعبير والمشاركة في كافة مناحي الحياة.

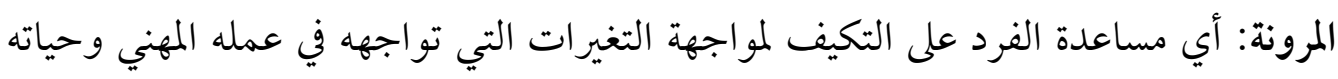

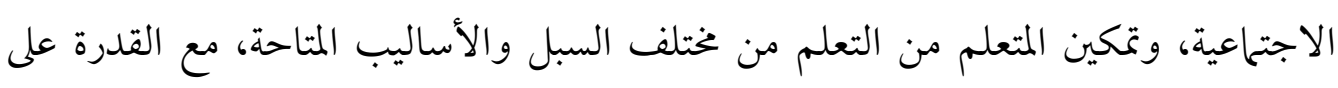
الاختيار بين بدائل من البرامج أو ورش العمل.

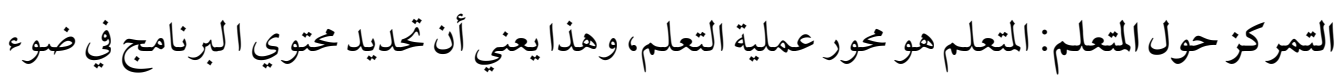
احتياجات المتعلمين أو المتدربين. ـ المعلم المتعلم: فالمعلم نفسه يلعب دور المتعلم المشارك كما يساعد على زيادة فاعلية التعلم، فالجميع مستمر في عملية التعلم دون توقف متعلم ومعلم.

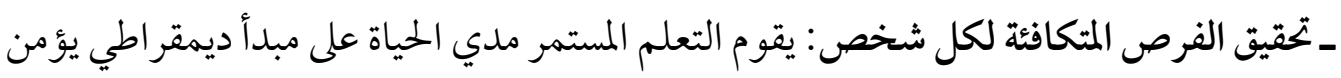

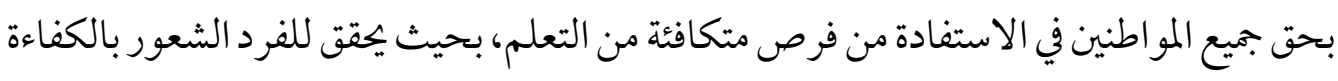
أو القدرة على التكيف مع كل جديد. المحور الثاني: المهارات القيادية واحتياجات الكبات كليار منها:

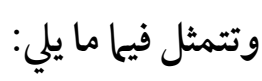
أولاً: أهمية القيادة للمؤسسات والأفراد. تركز هذه الدراسة على القيادات وتنمية مهارتهم ويرجع الاهتحام للاتي:(89)

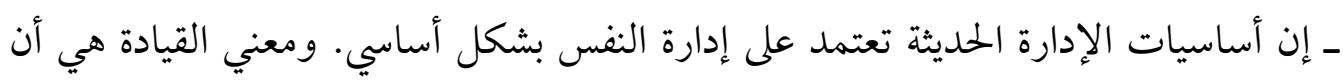

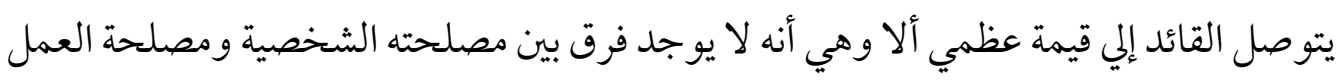
فالاهتحام بالنسبة له يكون واحد. 
ـ ليست القيادة في جوهرها توفير أشياء أو حتى تقديم رؤية، وإنما هي أن تهب نفسك وروحك معاً لمن أنت مسئول عنهم.

ـ أنها المسئول الأول لدعم القوي الإييابية في المؤسسة وتقليص الجو انب السلبية قدر الإمكان. ـ أنها تعمل على السيطرة على مشكلات العمل وحلها، وحسم الخلافات والترجيح بين الآراء. ـ أنها تعمل على تنمية وتدريب ورعاية الأفر اد باعتبارهم أهم مورد في للمؤسسة. ـ أنها همزة الوصل بين العاملين وبين خطط المؤسسة وتصور راتها المستقبلية. ـ أنها البوتقة التي تنصهر داخلها كافة المفاهيم والاستراتيجيات والسياسات. ـ أن الأفراد يتخذون من القيادات قضوه لهم. ـ أن من مهام القيادات توفير الظروف والبيئة التي تساعد على تطوير غيرهم من الموارد باعتبارهم أهم مورد في للمؤسسة. تمثل المهارات أحد المطالب الرئيسة للقيادات، حيث تعمل على تقدم وتفوق المؤسسات والأفر اد ليس هذا فقط، بل ومصدر لتحقيق نجاحها في تحقيق الأهداف المنشودة. ثانياً: تأثير مهارات القيادات على نجاح المؤسسات. هناك تأكيد من العديد من الباحثين والدراسات على أن المهارات شيء اساسي لنجاح

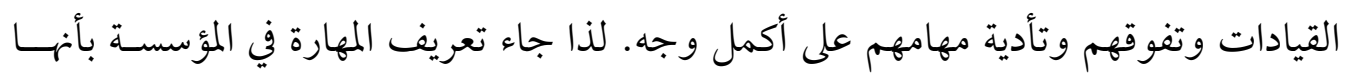

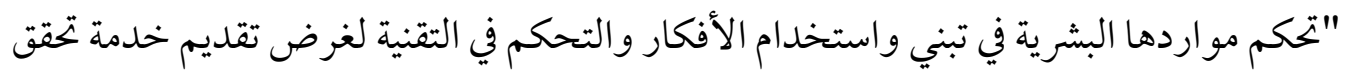

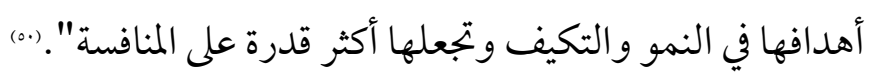
إن نمو المؤسسات وتحقيقها للنجاح مرتبط ارتباطاً وثيقاً بقدرتها على تنمية مهارات

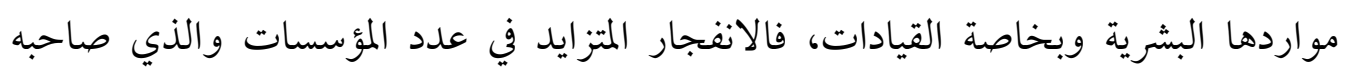
الانفجار التنافسي على المستوي العالمي، أدي إلى تصاعد الاهتحام بتنمية مهارات الموارد البشرية، 
والتركيز عليه وأصبحت القدرة على توفير برامج تعلم تلبي احتياجاتهم الحقيقية مصدرا متجدداً للميزة التنافسية، وأصبح هذا الدور ـ تنمية المهارة ـ مها في تدعيم الاستراتيجيات وتعزيزها في المؤسسة. فالمؤسسة التي تتحكم في المهارات الفنية والتقنية يمكنها تخفيض تكاليف الإنتاج وتحقيق أرباح إضافية ويمكنها إنشاء تشكيلة واسعة من المنتجات ذات جودة عالية تمكنها من كسب عو ائد مالية وهذا لانفر ادها بميزة المنتجات الجديدة. لذا يرتبط موضوع المهارة في أي مؤسسة ارتباطاً دلاليا مع موضوع القيادة، فالقائد هو العنصر الأساسي والأكثر احتكاكا بمفردات العمل التنظيمي والسلوك الإنساني داخل أية مؤسسة، فضلا عن كونه حلقة الوصل بين الميدان والمو اقع المشروعة للقرارات و المهارات.

ثالثاً: سمات وصفات القائد الفعال: إن الحديث عن المهارات المكتسبة يجعلنا لا نتجاهل فكرة السمات أو الصفات الشخصية للقائد وأثرها البالغ الأهمية في العملية القيادية، لذا قبل تحديد احتياجات القيادات من المهارات، تم عرض أهم السمات والصفات الشخصية للقادة كالاتي: ا ـ القدرة على اتخاذ القرار.

$$
\text { r النزاهة }
$$$$
\text { كـ الحماسة. }
$$$$
\text { عـ التخيل. }
$$

0_ الاستعداد للعمل بجد.

7ـ القدرة على التحليل.

$$
\text { Vـ فهم الآخرين. }
$$

^ـ القدرة على تحديد الفرص.

9ـ القدرة عللي مو اجهة المو اقف السيئة. • ـ ـ القدرة على التأقلم بسرعة مع التغيير. 
ا ـ الاستعداد لتحمل المخاطر.

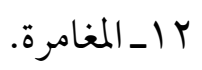

או ـ القدرة على التحدث بوضوح.

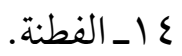

0 ـ ـ القدرة على الإدارة بكفاءة. ا 1 ـ تفتح العقل. V ا ـ القدرة على "المثابرة".

1 ـ ـ الاستعداد للعمل لساعات طويلة.

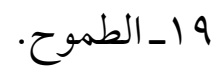

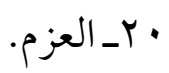
ا ا ـ القدرة على الكتابة بوضوح.

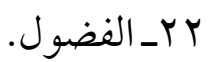
بr المهارة الرياضية.

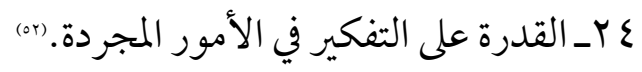
ه _ الثقة بالنفس وطلاقة اللسان. r ـ ـ النضج العاطفي. - IV _ الإلمام الكامل بالعلاقات الإنسانية. ^ ـ ـ القوة البدنية و السلامة النفسية. و ـ ـ التضحية: يضحي برغباته واحتياجاته الشخصية من أجل الصالح العام. •r ـ الحزم والثقة في اتخاذ القرار ات المستعجلة والاستعداد للعمل بها.

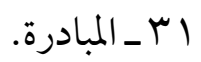

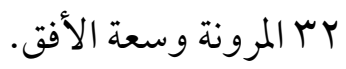
سب ـ القدرة على ضبط النفس عند اللزوم. 


$$
\begin{aligned}
& \text { ع ـ ـ المظهر الحسن. } \\
& \text { هـ السرعة في اختيار البدائل المناسبة. } \\
& \text { جسـ_احترام النفس واحترام الغير. }
\end{aligned}
$$

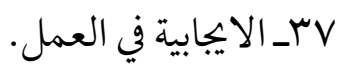

$$
\begin{aligned}
& \text { ^ץ_ القدرة على الابتكار وحسن التصرف. }
\end{aligned}
$$

و ب ـ أن تتسم علاقاته مع زملائه ورؤسائه ومرؤوسيه بالتعاون. (or)

\section{رابعاً: أهم احتياجات الكبار من المهارات القيادية.}

"جيش من الأرانب يقوده أسد، أفضل من جيش من الأسود يقوده أرنب، مقولة شهيرة

للقائد الفرنسي نابليون تحمل في طياتها معاني قوية تمجد القيادة وصفات القادة، لأن مهار ات القائد وصفاته قد تغطي على نواحي ضعف كبيرة قد تو جد لدي المرؤوسين بحسن التوجيه والتخطيط والرؤيا الثاقبة ومهار ات اكتشاف أوجه الضعف ومعالجتها، كلها صفات قد تغطي على ضعف المرؤوسين، بينحا نقص الخبرة وعدم وجود رؤي استراتيجية وضيق الأفق و الصدر، قد يحولوا في معظم الأحيان، بين القادة وتحقيق الأهداف، حتي وان كانت الوسائل متاحة والمرؤوسين أكفاء، وبها أن الأمر كذلك، فإن القيادات تحتاج لمجموعة من المهارات في نواحي مختلفة، بحيث يكونوا قادرين على التأثير الإيجابي في الآخرين لبلوغ الأهداف المنشودة.

ويمكن أن نفرق هنا بين ثلاثة أنواع من المهارات التي يجب أن تتوفر في القائد وهي: (o8) ا- المهارات الفكرية: وهي أن يتمتع القائد بالقدرة على الدراسة والتحليل والاستنتاج والاستعداد لتقبل أفكار الآخرين، ومن أهمها مهارة كل من: بناء الاستراتيجيات وتنمية السياسات، والتخطيط الاستراتيجي، والاستنتاج واستقراء المؤشرات، ومهارات تحليل 
المشكلات والكشف عن الأسباب، ومهارات إدارة المواقف ورصد المتغيرات، ومهارات

$$
\text { إدارة المعلومات والتعامل مع المتغيرات، ومهارات التفاوض. }
$$

rـ المهارات الإنسانية: وتتعلق بالطريقة التي يستطيع بها القائد التعامل بنجاح مع الآخرين

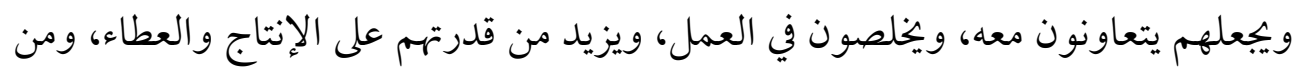
أهمها مهارات اختيار، وارشاد، وتطوير، وتمكين، وتنمية المساعدين، ومهارة كل من: التو اصل، ويناء فرق العمل المتعاونة، وتحفيز وتشجيع المساعدين. rــ المهارة الفنية التقنية: بالنسبة للمهارة الفنية أي كل ما يتعلق بإدارة العمل وسلوكير وسياته. و المقصود بالتقنية كل ما يتعلق بالتكنولوجيا المستخدمة في مجال العمل ومن أهم المهارات الفنية والتقنية مهارة كل من: إدارة العمل، واستخدام التكنولوجيا وتقنية المعلومات، وتطوير تقنيات العمل، ومهارات إدارة واستثمار الوقت، ومهارات إدارة الاجتماعات، وتطوير سلوكيات العمل . المحور الثالث: الواقع الراهن لتنمية المهارات القيادية لدي الكبار بيرامج التعلم المستمر مدي الحياة (الدراسة الميدانية). تمهيد: في هذا المحور تحاول الدراسة التعرف على واقع تنمية المهارات القيادية لدي الكبار

$$
\begin{aligned}
& \text { ببرامج التعلم المستمر مدي الحياة؛ بهدف الكشف عن واقع المشكلات التي تو اجهها. } \\
& \text { أولاً: إجراءات الدراسة الميدانية: }
\end{aligned}
$$

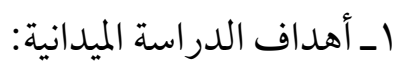

$$
\begin{aligned}
& \text { rـ أدوات الدراسة الميدانية - إعدادها وتقنينها. } \\
& \text { rـ اختيار ووصف عينة الدراسة. } \\
& \text { عـ تطبيق الاستبانة وتفريغ البيانات. } \\
& \text { ○ـتحليل نتائج الدراسة الميدانية وتفسيرها. }
\end{aligned}
$$


ثانياً: نتائج الدراسة الميدانية وتفسيرها: وتم تناول الواقع الر اهن كالتالي: أولاً: إجراءات الدراسة الميدانية:

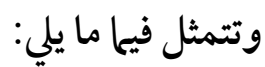
ـ ـ أهداف الدراسة الميدانية: تهدف الدراسة الميدانية إلي:

ا ـ التعرف على واقع تنمية المهارات القيادية لدي الكبار ببرامج التعلم المستمر مدي الحياة. rـ الكشف عن مشكلات ومعوقات برامج التعلم المستمر مدي الحياة الخاصة بتنمية المهارات القيادية لدي الكبار. ســـالتعرف على أهم احتياجات الكبار من المهارات القيادية. عـ تقويم برامج التعلم المستمر مدي الحياة الخاصة بتنمية المهارات القيادية لدي الكبار. 0ـوضع تصور مقترح لتنمية المهارات القيادية ببرامج التعلم المستمر مدي الحياة للكبار. r أداة الدراسة الميدانية: (إعدادها وتقنينها). استخدمت الدراسة الميدانية أداة الاستبانة، حيث أن توجيه أسئلة مختارة بعناية ومرتبة المبادية بدقة ومكمة إلى أفراد العينة هو الطريق العلمي للحصول على البيانات المطلوبة لقبول فرض أو رفضه، أو لجمع معلومات من الواقع. أــبناء الاستبانة في صورتها الأولية: قبل القيام بإعداد الاستبانة تم استخلاص عبارات المحاور، وذلك في ضوء مشكلة الدراسة، والهدف الذي تسعي إليه، حيث تم الاستعانة بأهم البحوث والدراسات السابقة، و الإطار النظري للدراسة، واستشارة بعض خبراء واساتذة الإدارة. وبناءً عليه تم صياغة العبارات استناداً إلى الشروط الواجب إتباعها عند صياغة عبارات وأسئلة الاستبانة من وضوح وملاءمة. 


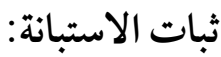

تم التحقق من ثبات الاستبانة بطريقة ألفا كرونباخ والجدول التالي يوضح معاملات ثبات أبعاد

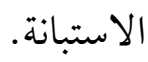

جدول (1): معاملات ثبات أبعاد الاستبانة وكذلك الدرجة الكلية

\begin{tabular}{|c|c|c|c|c|}
\hline \multicolumn{3}{|c|}{ الثاني } & \multirow[b]{2}{*}{ الأول } & \multirow{2}{*}{ البعد } \\
\hline ثالثاً & ثانياً & أولاًا & & \\
\hline$\cdot, \mathrm{\vee \wedge \Lambda}$ & $\cdot, \vee \vee 40$ & $\cdot$, , OV & $\cdot, \wedge r \varepsilon$ & معامل الثبات \\
\hline
\end{tabular}

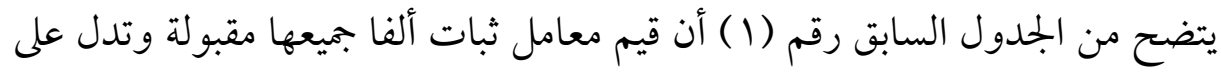

ثبات المحاور الفرعية والثبات القوي للاستبانة ككل.

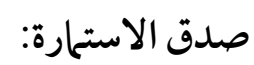

تم التأكد من صدق الاستحارة بالطريقتين التاليتين:

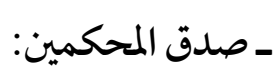

تم عرض الصورة الأولية للاستبانة على مجموعة من اساتذة الإدارة والخبراء المحكمين

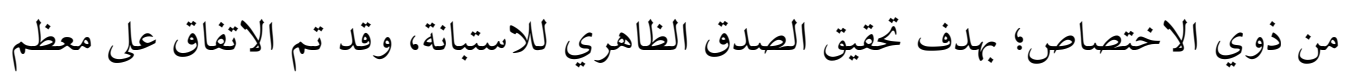

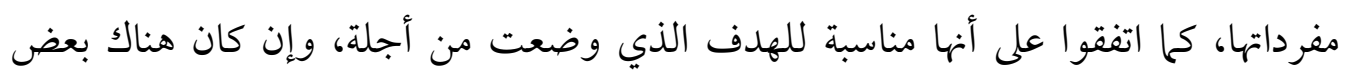
الملاحظات كما اتفقوا على أنها مناسبة للهدف الذي وضعت من من أجلة، وإن كان هناك الك بعض إنه الملاحظات البناءة والتي أفادت في إجراء بعض التعديلات على الصورة الأولية للاستبانة.

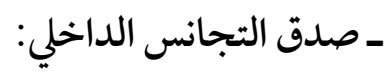
وذلك بحساب معامل الارتباط (المصحح) بين درجة كل عبارة وبموبع درجات المحور

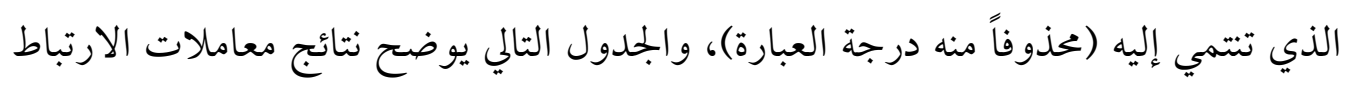

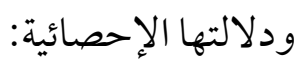


جدول (Y): معاملات الارتباط المصححة بين درجة كل عبارة والمحور الذي تنتمي إليه (ن= (r)

\begin{tabular}{|c|c|c|c|c|c|c|c|}
\hline \multicolumn{6}{|c|}{ المحور الثاني } & \multirow{2}{*}{\multicolumn{2}{|c|}{ المحور الأول }} \\
\hline \multicolumn{2}{|c|}{ ثالثاً } & \multicolumn{2}{|c|}{ ثانياً } & \multicolumn{2}{|c|}{ أولاً } & & \\
\hline معامل & رقم & معامل & رقم & معامل & رقم & معامل & رقم \\
\hline الارتباط & العبارة & الارتباط & العبارة & الارتباط & العبارة & الارتباط & العبارة \\
\hline$" \cdot, r_{0}$ & 1 & $" \cdot,{ }^{\prime}$ & 1 & $=, 01$ & 1 & $" \cdot, r \wedge$ & 1 \\
\hline$*$, , $\{0$ & r & a, 0 . & $r$ & $\cdots \cdot, \xi \mu$ & r & $*, 0 \leqslant$ & r \\
\hline$\cdots$ & $r$ & $\cdots, O Y$ & $r$ & $\cdots$, , $१$ १ & $r$ & $", r_{q}$ & $r$ \\
\hline$" \bullet$, ६ & $\varepsilon$ & $\cdots$, , $\{0$ & $\varepsilon$ & $", \varepsilon r$ & $\varepsilon$ & $\cdots$, or & $\varepsilon$ \\
\hline$=0, \leqslant 0$ & 0 & " " & 0 & $\cdots$, & 0 & $=$, , $\{7$ & 0 \\
\hline " • & 7 & $"$ ", & 7 & $\cdots, \_\vee$ & 7 & $"$ " & 7 \\
\hline & & $\cdots,\{\varepsilon$ & V & $\because, r \wedge$ & V & "• & V \\
\hline & & 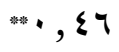 & $\wedge$ & $", r v$ & $\wedge$ & $\cdots,$, , ११ & $\wedge$ \\
\hline & & & & $*, r q$ & 9 & $\cdots$ & 9 \\
\hline & & & & $\cdots,\{\rceil$ & 1. & $*, \leqslant V$ & 1. \\
\hline & & & & $*,\{0$ & 11 & & \\
\hline & & & & سז, " & Ir & & \\
\hline
\end{tabular}

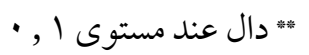

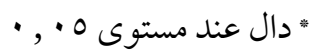

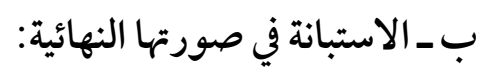

بعد الانتهاء من إجراء التعديلات في ضوء ملاحظات وتوجيهات السادة المحكمين،

أصبحت الاستبانة في صورتها النهائية، وتضم (Tr) عبارة موزعة على محورين فيا يلي:

المحور الأول: واقع دور برامج التعلم المستمر مدي الحياة في تنمية المهارات القيادية لدي الكبار (1·) 
المحور الثاني: احتياجات الكبار من المهارات القيادية (Y Y) عبارة، ويتضمن ثلاث أجزاء هي: ــ إلى أي مدي توفر برامج التعلم المستمر مدي الحياة المهارات الفكرية للقيادات؟ ( ا ( ) عبارة ــ إلى أي مدي توفر برامج التعلم المستمر مدي الحياة المهارات الإنسانية للقيادات؟ (^) عبارة ـ إلى أي مدي توفر برامج التعلم المستمر المهارات الفنية والتقنية للقيادات؟ (7) عبارات

\section{rـ اختيار ووصف عينة الدراسة:}

يصعب عادة عند دراسة ظاهرة معينة في مجتمع ما دراسة جميع أفراده، خاصة إذا كان هذا المجتمع كبيراً ومترامي الأطراف كما هو الحال بهذه الدراسة وفي هذه الحالة يلجأ الباحث إلي أسلوب أو طريقة يعبر بها عن المجتمع الأصلي بجميع صفاته. لذا تم اختيار العينة بصورة عشو ائية، مع مر اعاة متغيرات وخصائص المجتمع الأصلي والتي مها: ـ المحافظة: سو اء أكانت القاهرة أو بني سويف أو السويس أو جنوب سيناء. ـ اختلاف مكان العمل داخل المحافظة الواحدة لقيادات المؤسسات الحكومية والخاصة، وبعض مديري كل من: إدارة الموارد البشرية، ومر اكز التدريب ببعض المؤسسات الحكومية والخاصة.

وبعد توزيع الاستبانة على العينة وجمعها مرة أخري. تم عمل حصر شامل لجميع الاستبانات بعد استبعاد الاستبانات غير المكتملة، حيث قام الباحث بتوزيع (ب0 ا ) استبانة بأربع محافظات هم (القاهرة، وبني سويف، والسويس، وجنوب سيناء) وراعت الدراسة في اختيارها لهذه المحافظات اختلاف كل من: التوزيع الجغرافي ومستوياتها الاقتصادية والتنوع الثقافي وتعداداتها السكانية وبعد الخصر تم إجراء الإحصاءات على ( (10 ) استبانة فقـط، وهو عدد مناسب لأن عدد القيادات بالمؤسسات ليس كبير فكل مؤسسة أو إدارة أو قسم يقودها واحد فقط. وتمت جدولة هذه البيانات لتوضيح إجمالي خصائص عينة الدراسة فيا يلي: 
جدول (r): عدد مديري كل من: قيادات المؤسسات، وإدارة الموارد البشرية، ومر اكز التدريب بالمؤسسات

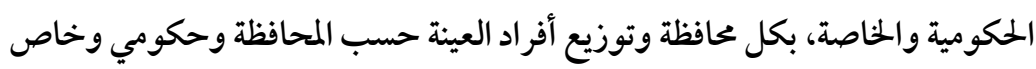

\begin{tabular}{|c|c|c|c|c|c|c|c|c|}
\hline \multirow{2}{*}{ المئوية } & \multirow[t]{2}{*}{ الإجمالي } & \multicolumn{2}{|c|}{ مديري إدارة مراكز } & \multicolumn{2}{|c|}{ مديري إدارة الموارد } & \multicolumn{2}{|c|}{ قيادات مؤسسات } & \multirow[t]{2}{*}{ المحافظة } \\
\hline & & خاص & حكومي & خاص & حكومي & خاص & حكومي & \\
\hline$\%$. . & 7. & $r$ & 0 & $\varepsilon$ & 11 & ir & ro & القاهرة \\
\hline$\%$ ro & rv & 1 & r & $r$ & $\wedge$ & 1 & IV & بني سويف \\
\hline$\% r r$ & rr & r & $r$ & $r$ & 7 & 0 & 10 & السويس \\
\hline$\%$ & $r$. & - & 1 & 1 & $\varepsilon$ & $r$ & 11 & جنوب سيناء \\
\hline$\% 1$. & 10. & & & & & & & إجمالي العينة \\
\hline
\end{tabular}

يتضح من الجدول السابق رقم (r) أن أكبر عدد من العينة بمحافظة القاهرة، حيث بلغت نسبته من إجمالي العينة (• ع.٪)، ويرجع ذلك لتركز أكبر عدد من سكان مصر بها، تلاها في العدد ححافظة بني سويف حيث بلغ عدد العينة بها (YV) بنسبة (0r/\%)، ثم محافظة السويس حيث بلغ

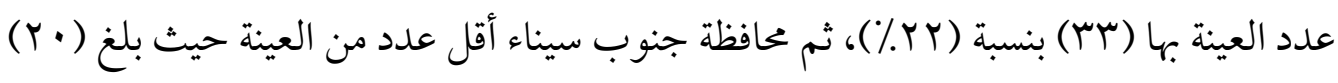
ونسبته من العينة الكلية (ب ( \%)، ويرجع ذلك لقلة عدد السكان بهذه المحافظة مقارنة بالمحافظات الثلاثة السالف ذكرها بالعينة. - تطبيق الاستبانة وتفريغ البيانات: حرص الباحث على تطبيق الاستبانة في صورة مقابلة شخصية مع أفراد العينة المختارة، وذلك لمراعاة ما يلي: شرح أسلوب الإجابة عن تساؤلات الاستبانة. ضمان صحة التطبيق من جهة وإزالة الغموض عن النقاط التي يتساءل عنها بعض أفراد العينة من جهة أخري، إذا ما دعت الضرورة إلى ذلك بصورة أكثر دقة ووضوحاً. الحصول على استجابة عالية لآراء أفراد العينة، والتقليل من احتمالات دهرة إهمال الاستبانة إذا

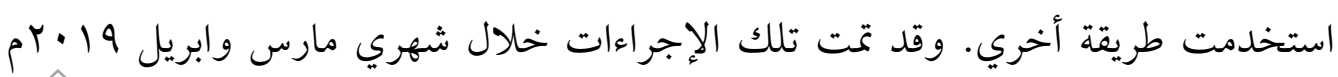


ويوضح الجدول التالي عدد الاستحارات الموزعة والفاقدة والعائدة والمستبعدة والصالحة من الاستبانة، والنسب المئوية للصالح منها. جدول (ع ): عدد الاستحارات الموزعة والفاقدة والمستبعدة والصالحة من الاستبانة والنسبة المئوية للصالح منها

\begin{tabular}{|c|c|c|c|c|}
\hline$\%$ & الصالح & المستبعد & الفاقد & الموزع \\
\hline$\% 91$ & 10. & 1 & $r$ & אo \\
\hline
\end{tabular}

يتبين من بيانات الجمدول السابق رقم (ع) أن إجمالي عدد الاستمارات الصالحة من

$$
\text { الاستبانة ( • 10 ) استمارة بنسبة (91\%٪) من إجمالي الموزع. }
$$

\section{ثانياً: نتائج الدراسة الميدانية وتفسيرها:}

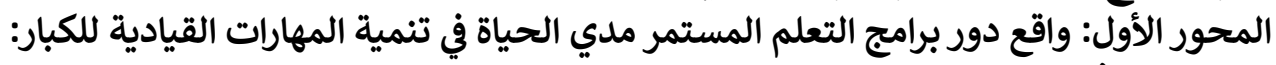

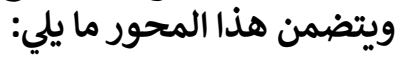

ـ إلى أي مدى تحقق برامج التعلم المستمر مدى الحياة دور ها في تنمية المهارات القيادية للكبار؟ جدول (ه): دلالة الفروق بين استجابة أفراد العينة نحو واقع برامج التعلم المستمر مدي الحياة في تنمية المهارات القيادية للكبار

\begin{tabular}{|c|c|c|c|c|c|c|c|c|}
\hline \multicolumn{7}{|c|}{ الاستجابة } & \multirow{3}{*}{ العبارات } & \\
\hline \multirow{2}{*}{ كاי } & \multicolumn{2}{|c|}{ ل } & \multicolumn{2}{|c|}{ إلى حد ما } & \multicolumn{2}{|c|}{ نعم } & & p \\
\hline & $\%$ & 5) & $\%$ & 5) & $\%$ & 5) & & \\
\hline$=1 \cdot, \cdot 1$ & $\{0, \varepsilon$ & $7 \Lambda$ & $r q, r$ & $\varepsilon \varepsilon$ & $r 0, r$ & rᄉ & تعمل البرامج المقدمة للقيادات على نشر ثقافة التعلم المستمر. & 1 \\
\hline$\approx 90,17$ & $11, r$ & IV & $r 0, r$ & rᄉ & & 90 & تلبي برامج التعلم المستمر احتياجات القيادات من المهارات. & r \\
\hline$\Rightarrow \wedge \wedge 1, \varepsilon \wedge$ & $1 \varepsilon$, & YI & 11 & rV & $\uparrow \wedge, \cdot$ & $1 \cdot r$ & برامج التعلم المستمر الأهداف المنشودة. & $r$ \\
\hline$\because \triangle \wedge, \curlyvee \wedge$ & $r q, r$ & 09 & $0, r$ & $\wedge$ & $00, \varepsilon$ & $\wedge r$ & تُكسب برامج التعلم المستمر القيادات مهارات جديدة & $\varepsilon$ \\
\hline$=1,9, \ldots$ & $1 \cdots \cdot$ & 10 & $17, V$ & ro & vr,r & 11. & يتم التنسيق بين كافة المثار كين في وضع البرامج لمنع تكرارها. & 0 \\
\hline$\Rightarrow \mid \wedge Y, 0 Y$ & $7, V$ & 1. & $\wedge$ & Ir & $\Lambda 0, r$ & IYA & تعمل برامج التعلم المستمر على زيادة أداء القيادات في الميدان. & 7 \\
\hline$=19 r, \ldots$ & $r$ & 0 & 1. & 10 & $\wedge \uparrow, \vee$ & ir. & ير اعي في برامج التعلم المقدمة للقيادات خطط التنمية الوطنية. & V \\
\hline$=$ FYY,QT & $1, r$ & r & $7, V$ & 1. & $9 Y, \cdot$ & IrA & يوجد رقابة على برامج التعلم المستمر المقدمة للقيادات. & $\wedge$ \\
\hline$* \mid Y \backslash, \wedge \varepsilon$ & $1 \cdot, 7$ & 17 & $I Y, V$ & 19 & $V T, V$ & 110 & يتم تقويم البرامج المقدمة للقيادات باستمرار . & 9 \\
\hline${ }^{*} \wedge \varepsilon, Y \wedge$ & $0, r$ & $\wedge$ & $77, \cdot$ & 99 & $r \wedge, V$ & $\varepsilon r$ & يتم تقديم تغذية راجعة بعد الانتهاء من تقويم برامج التعلم & 1. \\
\hline
\end{tabular}




\section{يتضح من الجمدول السابق رقم (0) أن:}

-وجود فروق ذات دلالة إحصائية بين استجابات أفراد العينة نحو درجة تحقق العبارة الخاصة بـ تعمل البرامج المقدمة للقيادات على نشر ثقافة التعلم المستمر، حيث جاءت قيمة كان المحسوبة

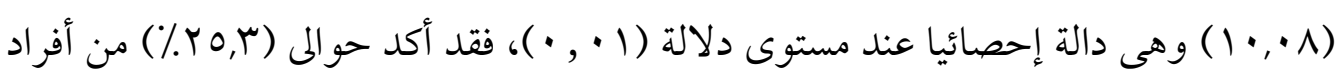
العينة تحقيق هذا الدور في الواقع الفعلي، بينما ترى نسبة (ب,ه Y.٪) منهم أنه يتحقق إلى حد ما، في

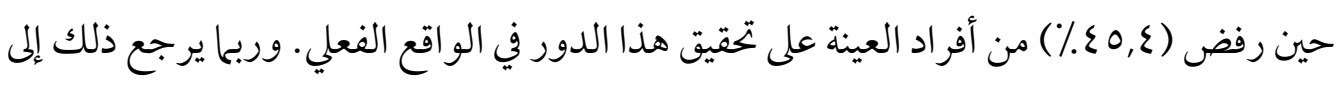
أن البرامج المعدة تركز على اكسابهم المعلومات والمهارات فقط، ولا تلقي بالاً لأهمية أن يستمر المتعلم بعد انتهاء البرنامج في التعلم. ـ وجود فروق ذات دلالة إحصائية بين استجابات أفر اد العينة نحو درجة تحقق العبارة الخاصة بـ تلبي برامج التعلم المستمر احتياجات القيادات من المهارات، حيث جاءت قيمة كان المحسوبة

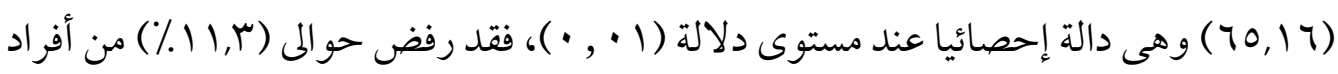
العينة تحقيق هذا الدور في الواقع الفعلي، بينما ترى نسبة (ro, Y.٪) منهم أنه يتحقق إلى حد ما، في حين أكد (ع,rا7\%) من أفراد العينة على تحقيق هذا الدور في الواقع الفعلي. يرجع ذلك إلى أنه يتم التعرف على احتياجات لقيادات قبل إعداد برامج التعلم المستمر، إلا أن هناك نسبة أكثر من (• (٪) ذكرو بأن هذه البرامج لا تقوم بهذا الدور مما يعني أن هناك حاجة إلى التأكد من أن هذه البرامج المعدة تلبي احتياجات القيادات من المهارات عند إعداد البرامج الخاصة بالقيادات. - وجود فروق ذات دلالة إحصائية بين استجابات أفراد العينة نحو درجة تحقق العبارة الخاصة بـ

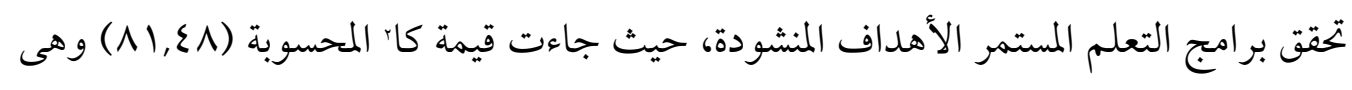
دالة إحصائيا عند مستوى دلالة (1 + , ·)، فقد رفض حوالى (ع (٪) من أفراد العينة تحقيق هذا

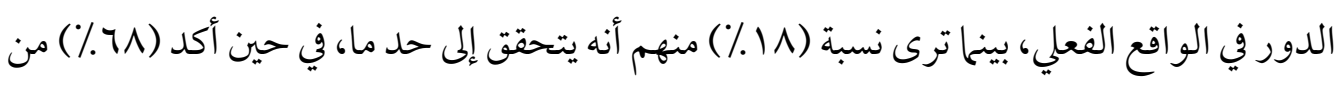


أفراد العينة على تحقيق هذا الدور في الواقع الفعلي. وهذا مرجعه إلى أنه في الغالب يتم مراعاة

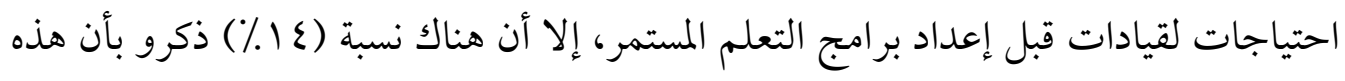
لبرامج لا تقوم بهذا الدور مما يعني أن هناك حاجة إلى إعادة النظر في هذا الأمر. ـوجود فروق ذات دلالة إحصائية بين استجابات أفراد العينة نحو درجة تحقق العبارة الخاصة بـ

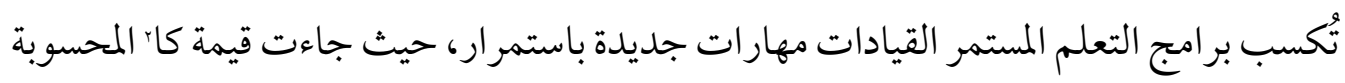

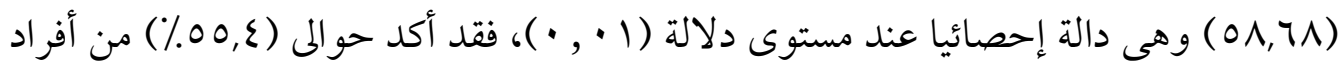

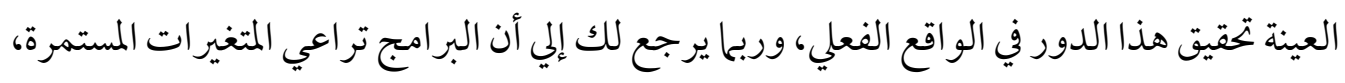

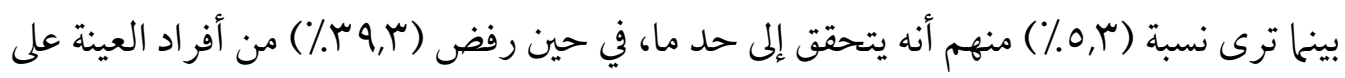
تحقيق هذا الدور في الواقع الفعلي. ويرجع ذلك إلى أن البرامج المعدة لا يتم تحديثها أو تغييرها لفترة طويلة، وريها يتم تقديم نفس البرامج بنفس المادة العلمية لنفس القيادات مرة أخري. - وجود فروق ذات دلالة إحصائية بين استجابات أفراد العينة نحو درجة تحقق العبارة الخاصة بـ

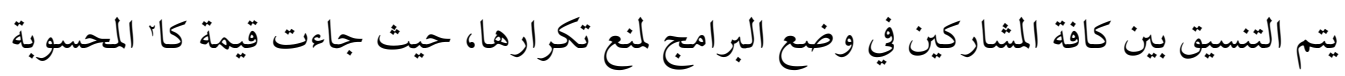

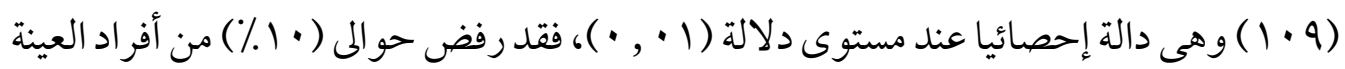

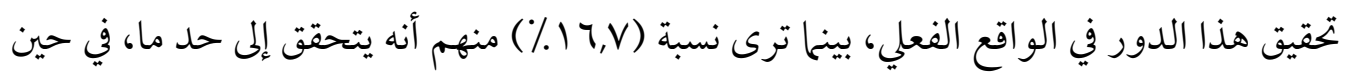

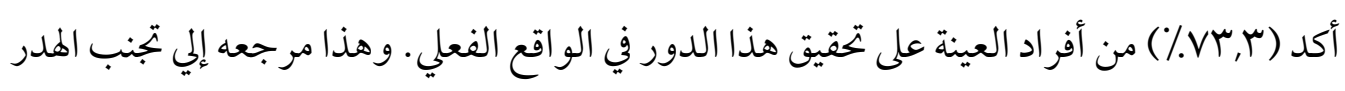
في النفقات والوقت والجها، إلا أنه ناك نسبة (• (1\%) ذكرو بأن هذه البرامج لا تقوم بهذا الدور

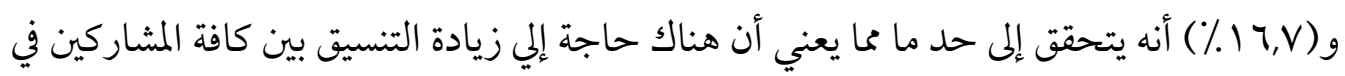

$$
\text { وضع البرامج لتحقيق الهدف منها بنسبة ( . (1\%). }
$$

ـ وجود فروق ذات دلالة إحصائية بين استجابات أفراد العينة نحو درجة تحقق العبارة الخاصة بـ تعمل برامج التعلم المستمر على زيادة أداء القيادات في الميدان، حيث جاءت قيمة كاء المحسوبة تردية 


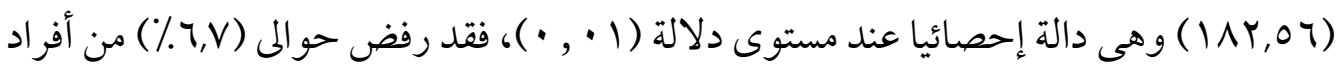
العينة تحقيق هذا الدور في الواقع الفعلي، بينحا ترى نسبة (^.٪) منهم أنه يتحقق إلى حد ما، في حين أكد (ro,^٪) من أفراد العينة على تحقيق هذا الدور في الو اقع الفعلي. وذلك يؤكد على أهمية تنمية مهارات القيادات باستمر ار. كما يؤكد على أهمية هذه الدراسة.

- وجود فروق ذات دلالة إحصائية بين استجابات أفراد العينة نحو درجة تحقق العبارة الخاصة بـ يراعى في برامج التعلم المقدمة للقيادات خطط التنمية الوطنية، حيث جاءت قيمة كان المحسوبة

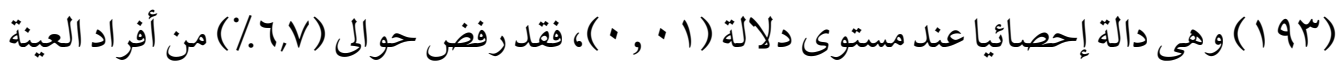
تحقيق هذا الدور في الواقع الفعلي، بينما ترى نسبة (^.٪) منهم أنه يتحقق إلى حد ما، في حين أكد (ro,r\%) من أفر اد العينة على تحقيق هذا الدور في الواقع الفعلي. وربها يرجع ذلك إلى أن التعلم المستمر مدي الحياة من ضمن أهدافه الرئيسة العمل على التنمية الشاملة.

- وجود فروق ذات دلالة إحصائية بين استجابات أفراد العينة نحو درجة تحقق العبارة الخاصة بـ يوجد رقابة على برامج التعلم المستمر المقدمة للقيادات، حيث جاءت قيمة كان المحسوبة

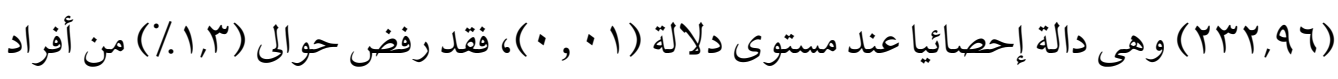
العينة تحقيق هذا الدور في الواقع الفعلي، بينما ترى نسبة (7,V.٪) منهم أنه يتحقق إلى حد ما، في حين أكد (r9\%) من أفراد العينة على تحقيق هذا الدور في الواقع الفعلي. وهذا مرجعه إلى إدراك أهمية المتابعة لنجاح برامج التعلم المستمر. - وجود فروق ذات دلالة إحصائية بين استجابات أفراد العينة نحو درجة تحقق العبارة الخاصة بـ

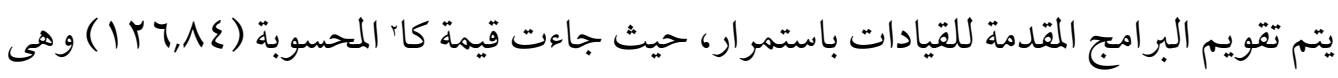
دالة إحصائيا عند مستوى دلالة (1 · , • )، فقد رفض حوالى (7, • ( ٪) من أفراد العينة تحقيق هذا

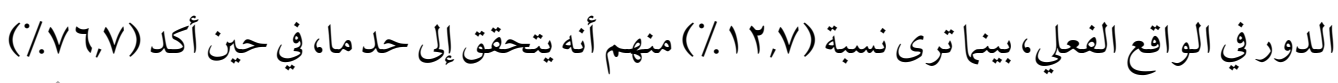


من أفراد العينة على تحقيق هذا الدور في الو اقع الفعلي. ويرجع ذلك إلى التأكد من تحقق أهداف

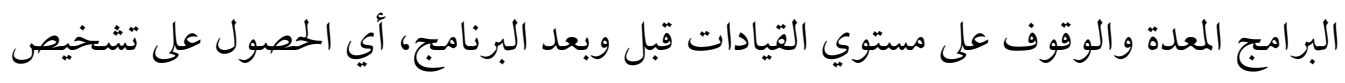
جيد، ووضع العلاج المناسب أذا اقتضي الأمر. - وجود فروق ذات دلالة إحصائية بين استجابات أفراد العينة نحو درجة تحقق العبارة الخاصة يتم تقديم تغذية راجعة بعد الانتهاء من تقويم برامج التعلم المستمر، حيث جاءت قيمة كاء المحسوبة

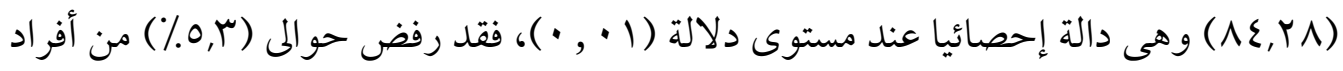
العينة تحقيق هذا الدور في الواقع الفعلي، بينما ترى نسبة (77\%) منهم أنه يتحقق إلى حد ما، في حين

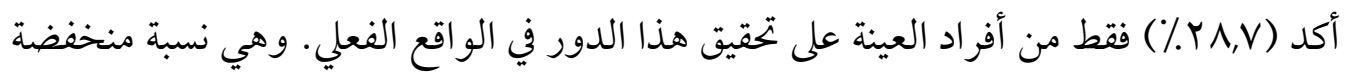
وهو ما يجب أن يأخذ في الاعتبار من قبل المسئو لين عن برامج التعلم المستمر التي تقدم للقيادات.

\section{المحور الثاني: احتياجات الكبار المهارات القيادية:}

ويتضمن هذا المحور ما يلي: - اجيات

1 إ إلى أي مدي توفر برامج التعلم المستمر مدي الحياة المهارات الفكرية للقيادات الكبار؟

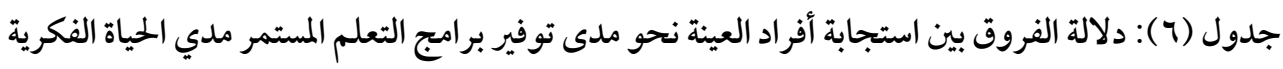
للقيادات للكبار

\begin{tabular}{|c|c|c|c|c|c|c|c|c|}
\hline \multicolumn{7}{|c|}{ الاستجابة } & \multirow{3}{*}{ العبارات } & \multirow{3}{*}{ p } \\
\hline \multirow[b]{2}{*}{ كاי } & \multicolumn{2}{|c|}{ لا } & \multicolumn{2}{|c|}{ إلى حد ما } & \multicolumn{2}{|c|}{ نعم } & & \\
\hline & $\%$ & 5) & $\%$ & 5) & $\%$ & 5 & & \\
\hline * I Y & $9, r$ & $1 \varepsilon$ & $1 \xi, V$ & Yr & $V 7, \cdot$ & 118 & تنمي برامج التعلم المستمر مدي الحياة مهارة & 1 \\
\hline$\cdots\{9, \leqslant \wedge$ & rq, & $0\}$ & $\Lambda, \vee$ & ir & $00, r$ & $\Lambda r$ & تلبي برامج التعلم المستمر احتياجات القيادات & $r$ \\
\hline$\cdots v \cdot, i \Lambda$ & $1 \cdot, \mathrm{V}$ & 17 & $Y \varepsilon, T$ & rv & $T \xi, V$ & 9V & رصدمل برامج التعلم المستمر على تنمية مهارة & r \\
\hline
\end{tabular}




\begin{tabular}{|c|c|c|c|c|c|c|c|c|}
\hline \multicolumn{7}{|c|}{ الاستحابة } & \multirow{3}{*}{ 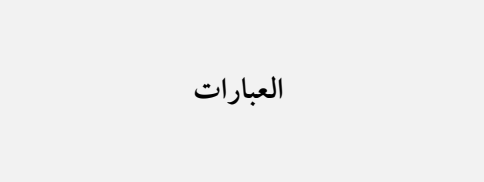 } & \multirow{3}{*}{$\rho$} \\
\hline \multirow[b]{2}{*}{ كاי } & \multicolumn{2}{|c|}{ لا } & \multicolumn{2}{|c|}{ 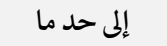 } & \multicolumn{2}{|c|}{ نعم } & & \\
\hline & $\%$ & 5 & $\%$ & 5) & $\%$ & ك & & \\
\hline$=1 \cdot r, \varepsilon \Lambda$ & $\Lambda, \vee$ & ir & $19, r$ & rq & $\forall r^{\prime} \cdot$ & $1 \cdot 1$ & تلنمي برامج التعلم المستمر مهارة التعامل مع & $\varepsilon$ \\
\hline$=V Q, r Y$ & rч, & rq & $\wedge, \cdot$ & ir & $77, \cdot$ & 99 & المع اقفل برامج التعلم المستمر على تنمية مهارة إدارة & ○ \\
\hline$\cdots\{0, Y \wedge$ & $0 \cdot, V$ & Vy & $\wedge, \cdot$ & Ir & $\varepsilon 1, r$ & TY & تُكسب برامج التعلم القيادات الكبار مهارة & 7 \\
\hline$=100,07$ & $\Lambda, V$ & ir & $1 \cdot, \cdot$ & 10 & $\wedge 1, r$ & Irr & يتم توظيف برامج التعلم المستمر في تنمية مهارة & $\checkmark$ \\
\hline$=r\{, 17$ & $\{0, r$ & 71 & $1 \varepsilon, V$ & rY & $\varepsilon \cdot, \cdot$ & 7. & تُكسب برامج التعلم المستمر القيادات مهارة & $\wedge$ \\
\hline$\cdots \wedge 1, V^{\prime}$ & $\Lambda, \cdot$ & Ir & $r 0, r$ & ґ^ & $74, \mathrm{~V}$ & $1 \cdots$ & تعمل برامج التعلم المستمر على تنمية مهارة & 9 \\
\hline$=Y \mid V, 97$ & $1, r$ & r & $\Lambda, \vee$ & ir & $9 \cdot, \cdot$ & iro & تنمي بر امج التعلم المستمر مهارة التفاوض. & 1 . \\
\hline$* Y \wedge, 94$ & $\{\wedge, \cdot$ & VY & $\mid r, r$ & $r \cdot$ & $r \wedge, V$ & $0 \wedge$ & تُكسب برامج التعلم القيادات مهارة إدارة & 11 \\
\hline$\because q V, r Y$ & $\Lambda, V$ & ir & $Y \cdot, T$ & rl & $v \cdot, v$ & 1.7 & تنمي بر امج التعلم مهارة بناء الاستراتيجيات. & Ir \\
\hline
\end{tabular}

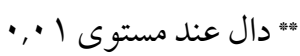

يتضح من الجدول السابق رقم (7) أن:

ـ وجود فروق ذات دلالة إحصائية بين استجابات أفراد العينة نحو درجة تحقق العبارة الخاصة بـ تنمي برامج التعلم المستمر مدي الحياة مهارة التخطيط الاستراتيجي للقيادات الكبار، حيث

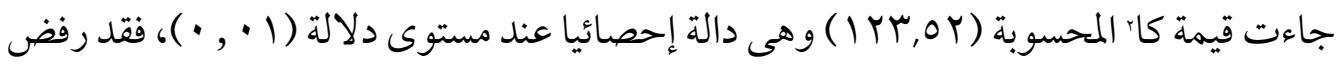




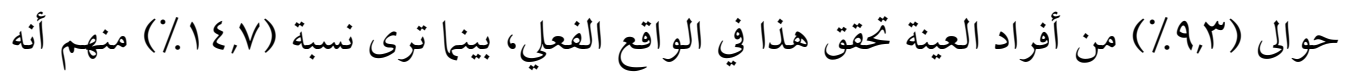
يتحقق إلى حد ما، في حين أكد (TV٪) من أفر اد العينة على تحقق هذه المهارة في الواقع الفعلي. ويرجع ذلك إلى أهمية التخطيط الاستراتيجي للقيادات. - وجود فروق ذات دلالة إحصائية بين استجابات أفراد العينة نحو درجة تحقق العبارة الخاصة

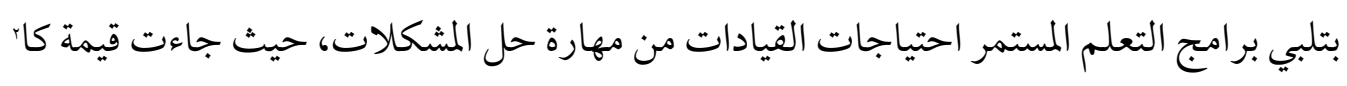

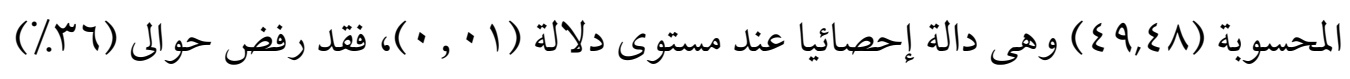

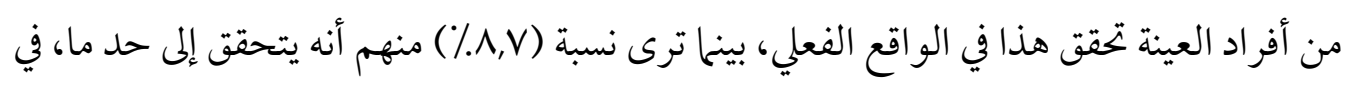

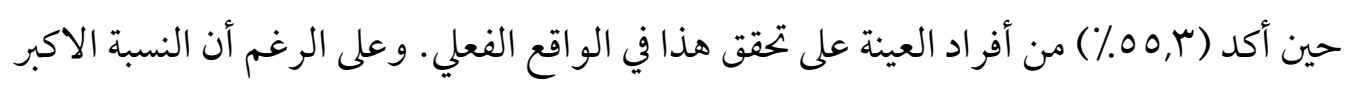

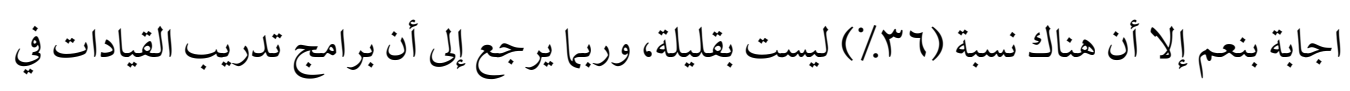

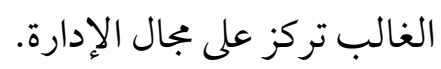

ـ وجود فروق ذات دلالة إحصائية بين استجابات أفراد العينة نحو درجة تحقق العبارة الخاصة بـ تعمل برامج التعلم المستمر على تنمية مهارة رصد المتغيرات، حيث جاءت قيمة كاء المحسوبة بهربة

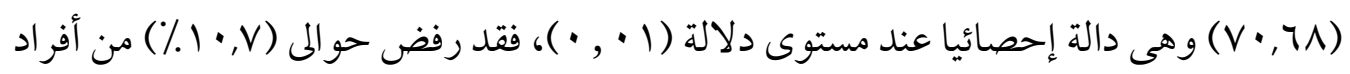

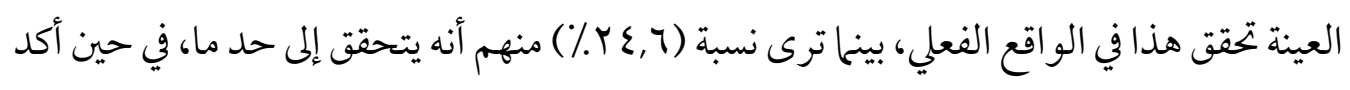

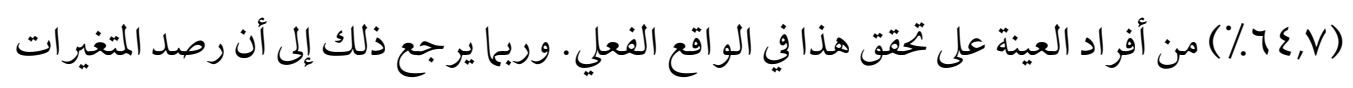
من قبل القيادات يجعلهم قادرين على الاطلاع على المتغيرات الجديدة. - وجود فروق ذات دلالة إحصائية بين استجابات أفراد العينة نحو درجة تحقق العبارة الخاصة

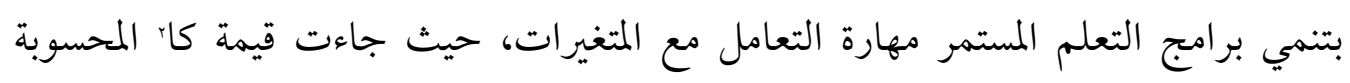

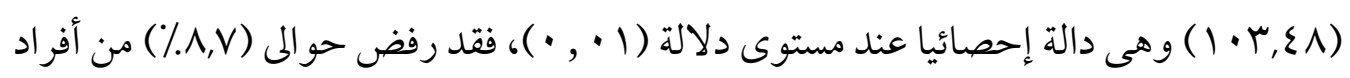

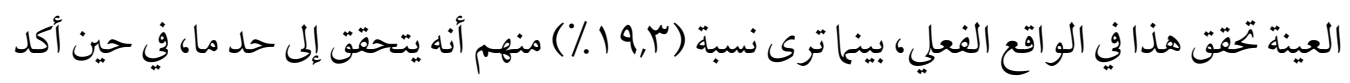




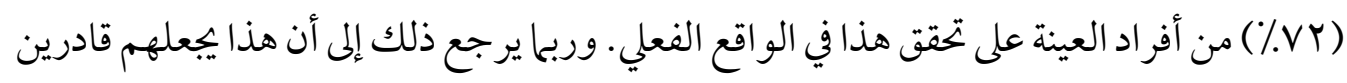

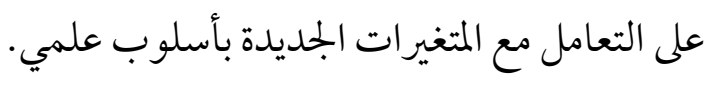
ـ وجود فروق ذات دلالة إحصائية بين استجابات أفراد العينة نحو درجة تحقق العبارة الخاصة بـ تعمل برامج التعلم المستمر على تنمية مهارة إدارة المواقف، حيث جاءت قيمة كان المحسوبة

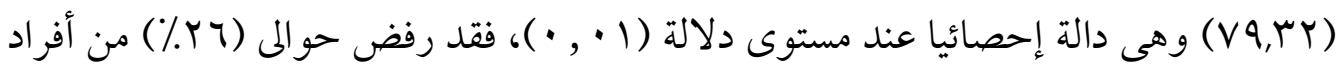

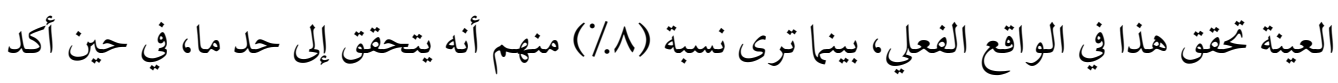

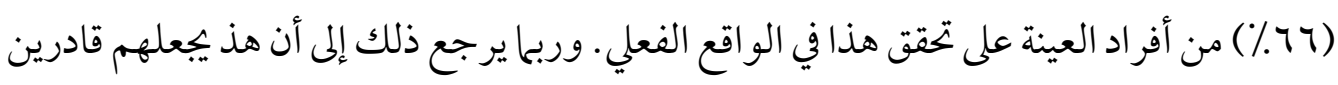

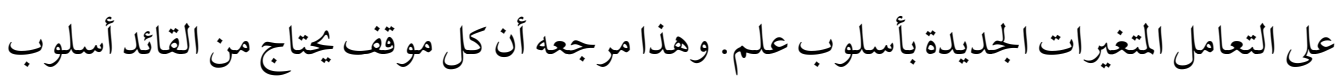

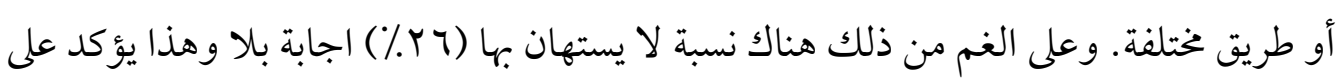
ضرورة إعادة النظر في برامج التعلم الخاصة بتنمية المهارات القيادية. ـ وجود فروق ذات دلالة إحصائية بين استجابات أفراد العينة نحو درجة تحقق العبارة الخاصة

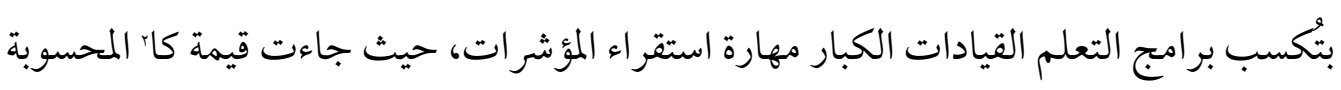

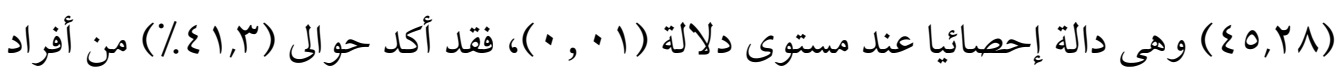

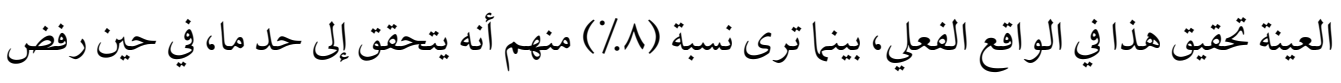

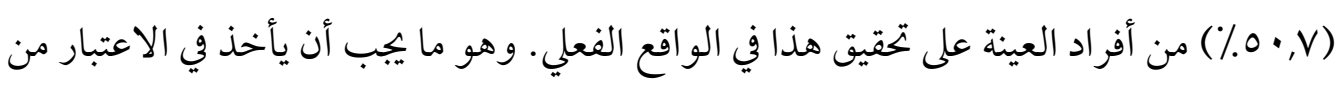
قبل المسئولين عن برامج التعلم المستمر عند تخطيط وإعداد برامج التعلم المستمر. ـوجود فروق ذات دلالة إحصائية بين استجابات أفراد العينة نحو درجة تحقق العبارة الخاصة بـ

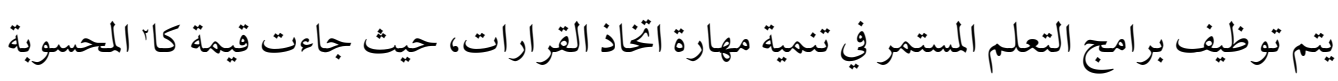

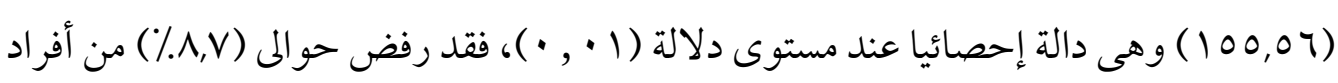

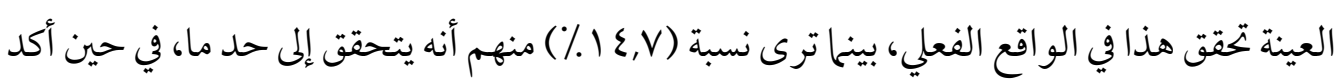




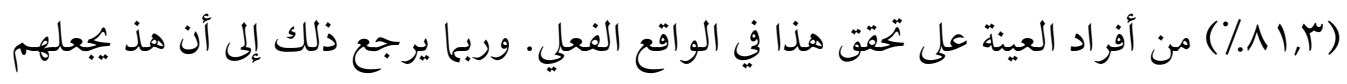

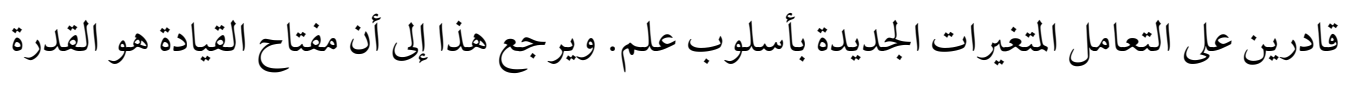
على اتخاذ القرار المناسب في الوقت المناسب. ـ وجود فروق ذات دلالة إحصائية بين استجابات أفراد العينة نحو درجة تحقق العبارة الخاصة بـ

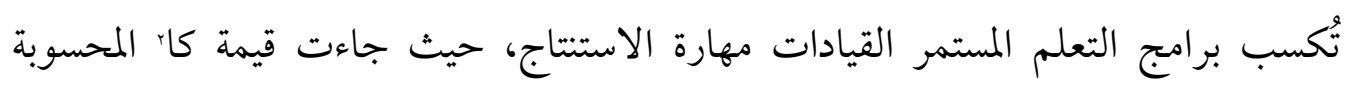

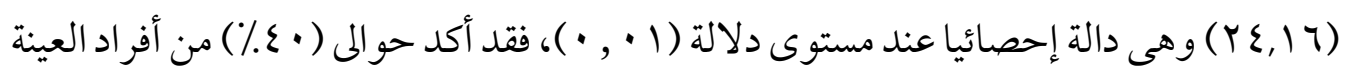
تحقق هذا في الو اقع الفعلي، بينما ترى نسبة (V,V ( I\%) منهم أنه يتحقق إلى حد ما، في حين رفض

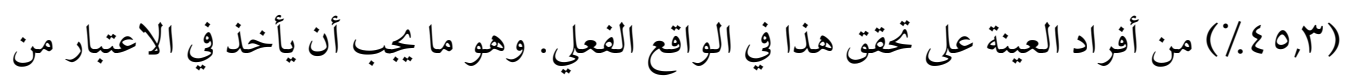
قبل المسئو لين عن برامج التعلم المستمر عند تخطيط وإعداد برامج التعلم المستمر. ـ وجود فروق ذات دلالة إحصائية بين استجابات أفراد العينة نحو درجة تحقق العبارة الخاصة بـ

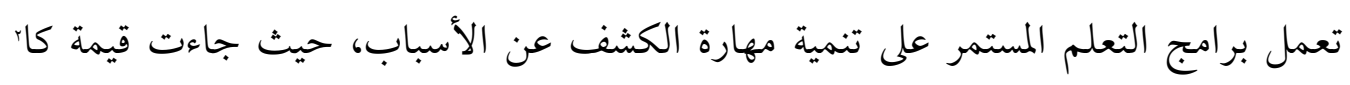

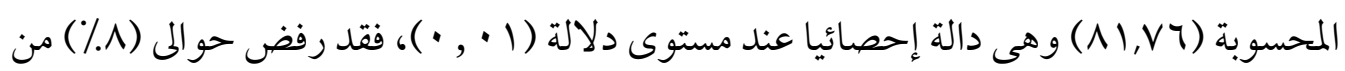

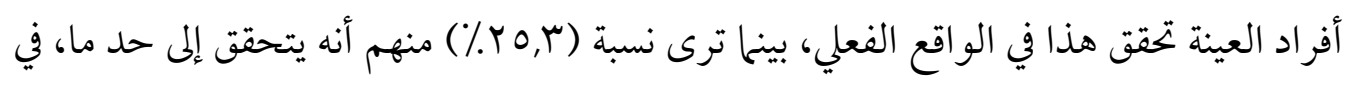

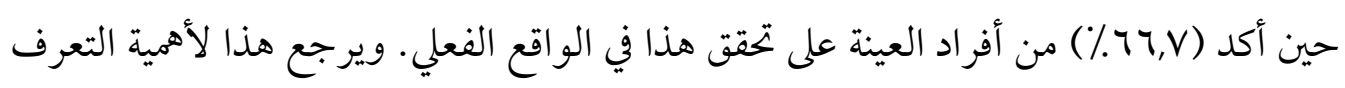
على الاسباب بهدف التشخيص ومن ثم العلاج.

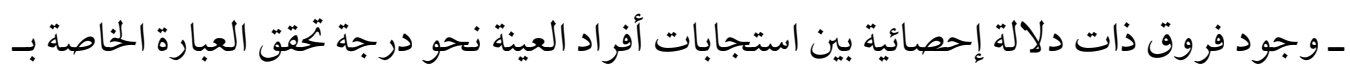

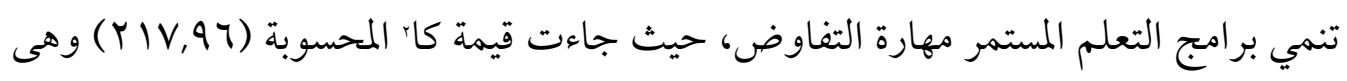

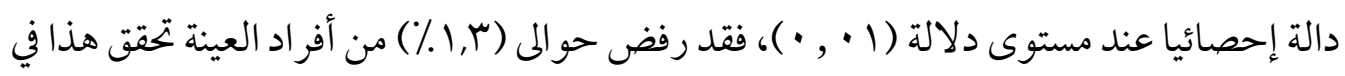

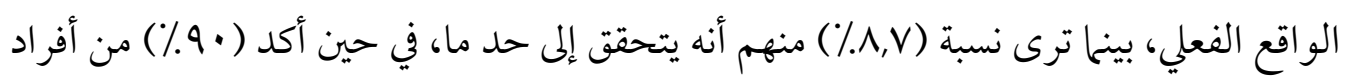
العينة على تحقق هذا في الو اقع الفعلي. ويرجع هذا الأهمية التفاوض للقيادات. 
- وجود فروق ذات دلالة إحصائية بين استجابات أفراد العينة نحو درجة تحقق العبارة الخاصة تُكسب برامج التعلم القيادات مهارة إدارة المعلو مات، حيث جاءت قيمة كاء المحسوبة (Y Y, Y )

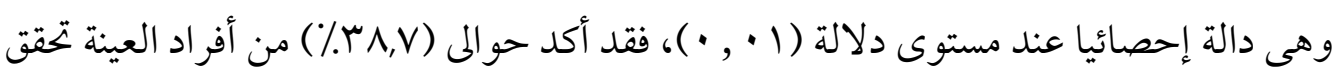

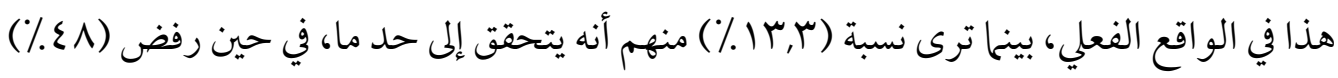
من أفر اد العينة على تحقق هذا في الو اقع الفعلي. وهو ما يجب أن يأخذ في الاعتبار من قبل المسئولين عن برامج التعلم المستمر عند تخطيط وإعداد برامج التعلم المستمر، فالمعلومات وإدارتها من الأشياء المهمة لأي قائد ناجح. - وجود فروق ذات دلالة إحصائية بين استجابات أفراد العينة نحو درجة تحقق العبارة الخاصة تنمي برامج التعلم مهارة بناء الاستراتيجيات، حيث جاءت قيمة كاء المحسوبة (YV,Y (9V) وهى

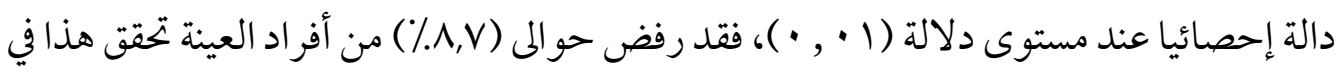

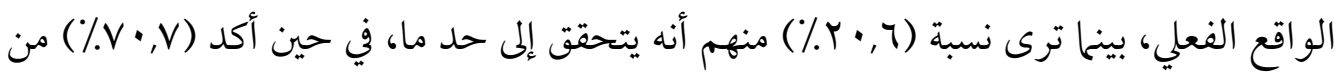
أفراد العينة على تحقق هذا في الواقع الفعلي. ويرجع هذا لان مهارة بناء الاستراتيجيات من المهارات الاساسية للقائد الفعال.

rـ إلى أي مدي توفر برامج التعلم المستمر مدي الحياة المهارات الإنسانية للقيادات الكبار؟ جدول (V) : دلالة الفروق بين استجابة أفراد العينة نحو مدى توفير برامج التعلم المستمر مدي الحياة المهارات الإنسانية للقيادات للكبار

\begin{tabular}{|c|c|c|c|c|c|c|c|c|}
\hline \multicolumn{7}{|c|}{ الاستجابة } & \multirow{3}{*}{ العبارات } & \multirow{3}{*}{ p } \\
\hline \multirow{2}{*}{ كا' } & \multicolumn{2}{|c|}{$\gamma$} & \multicolumn{2}{|c|}{ إلى حد مـا } & \multicolumn{2}{|c|}{ نعم } & & \\
\hline & $\%$ & ك & $\%$ & ك & $\%$ & ك & & \\
\hline$* * \checkmark, \vee, \wedge \Lambda$ & $r, \cdot$ & $r$ & $q, r$ & $1 \varepsilon$ & $\wedge \wedge, \vee$ & rr & الحياة القيادات مهارات التعلم المستمر مدي. & 1 \\
\hline 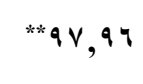 & $r \wedge, \cdot$ & $\varepsilon r$ & $r, r$ & ○ & $\checkmark \wedge, \vee$ & $1 \cdot r$ & 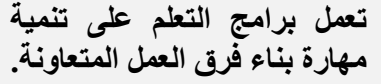 & $r$ \\
\hline
\end{tabular}




\begin{tabular}{|c|c|c|c|c|c|c|c|c|}
\hline \multirow{3}{*}{ كاי } & \multicolumn{6}{|c|}{ الاستجابة } & \multirow{3}{*}{ العبارات } & \multirow{3}{*}{ b } \\
\hline & \multicolumn{2}{|c|}{$\gamma$} & \multicolumn{2}{|c|}{ إلى حد ما } & \multicolumn{2}{|c|}{ نعم } & & \\
\hline & $\%$ & ك5 & $\%$ & ك5 & $\%$ & ك5 & & \\
\hline$* * r v, r q$ & $\varepsilon 0, r$ & 71 & $1 T, \varepsilon$ & $r$. & $\varepsilon 1, r$ & $7 r$ & تنهارة اختيار المساعدين. التعلم المستمر & $r$ \\
\hline$* * Y \backslash \wedge, \leq \varepsilon$ & $q, r$ & $1 \varepsilon$ & $\cdot, \mathrm{V}$ & 1 & $9 \cdot, \cdot$ & $1 \% 0$ & المساعدبن برامج التعلم مهارة تحفيز & $\varepsilon$ \\
\hline${ }^{* *} \vee \wedge, \mid r$ & $r v, r$ & $\leqslant 1$ & $v, \varepsilon$ & 11 & $70, r$ & $9 \wedge$ & تعهارة تنسيق عمل التعلم على تلمسين. & 0 \\
\hline$* * 40,1$ & $r q, r$ & $\leqslant \varepsilon$ & $\wedge, \vee$ & ir & $r{ }^{*}$ & 94 & الكبار مهارة إربـاد المساعدادين. & 7 \\
\hline${ }^{* *} \wedge \leq, 7 \leq$ & $r r, r$ & o. & $r, v$ & $\varepsilon$ & $7 \varepsilon$, & 97 & يتم توظيف برامج تطوير المساعدين. في تتمية & V \\
\hline$* * \wedge \uparrow, \neg \wedge$ & $\wedge, \vee$ & ir & 7, & 9 & $\Lambda 0, r$ & $\mid r k$ & تنمية مهارة تمكين المساعدين. & $\wedge$ \\
\hline
\end{tabular}

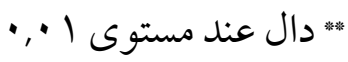
يتضح من الجدول السابق رقم (V) أن: - وجود فروق ذات دلالة إحصائية بين استجابات أفراد العينة نحو درجة تحقق العبارة الخاصة بتّكسب برامج التعلم المستمر مدي الحياة القيادات مهارات التواصل، حيث جاءت قيمة كان

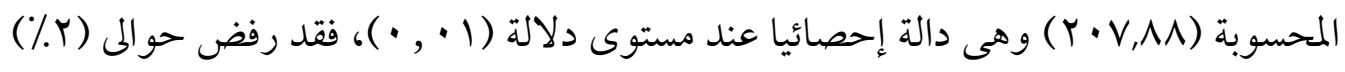
من أفر اد العينة تحقق هذا في الو اقع الفعلي، بينما ترى نسبة (r,9\%٪) منهم أنه يتحقق إلى حد ما، في

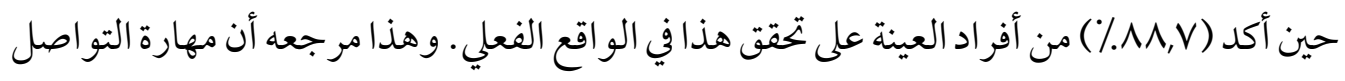
من المهار ات الهامة لنجاح للقائد فالتو اصل الجيد يؤدي لنجاح العمل وتحقيق الأهداف المنشودة. - وجود فروق ذات دلالة إحصائية بين استجابات أفراد العينة نحو درجة تحقق العبارة الخاصة بتعمل برامج التعلم على تنمية مهارة بناء فرق العمل المتعاونة، حيث جاءت قيمة كاء المحسوبة 
(9V,97) وهى دالة إحصائيا عند مستوى دلالة (1 · , •)، فقد رفض حوالى (Y^/\%) من أفراد العينة تحقق هذا في الواقع الفعلي، بينما ترى نسبة (r,r/\%) منهم أنه يتحقق إلى حد ما، في حين أكد (\% من أفراد العينة على تحقق هذا في الواقع الفعلي. ويرجع هذا لان نجاح العمل مبني على

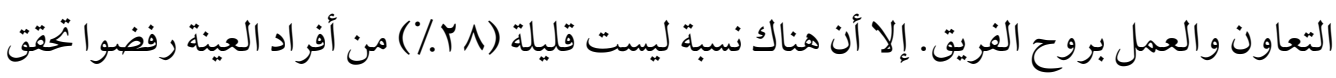
هذا في الو اقع، وربما يرجع ذلك لضعف التركيز على هذه المهارة في البرامج. - وجود فروق ذات دلالة إحصائية بين استجابات أفراد العينة نحو درجة تحقق العبارة الخاصة بـ تنمي برامج التعلم المستمر مهارة اختيار المساعدين، حيث جاءت قيمة كاء المحسوبة (TV,Y )

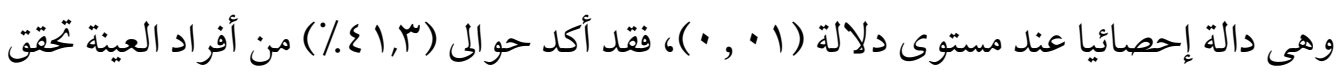

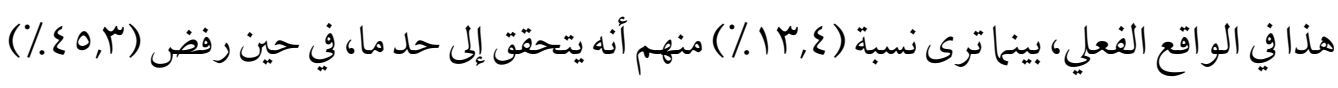
من أفراد العينة على تحقق هذا في الواقع الفعلي. وربها لضعف الوعي بأهمية اختيار المساعدين والذي عد من صميم أعحال القائد الناجح وهو ما يجب أن يأخذ في الاعتبار من قبل المسئولين عن بر امج التعلم المستمر عند تخطيطها وإعدادها. - وجود فروق ذات دلالة إحصائية بين استجابات أفراد العينة نحو درجة تحقق العبارة الخاصة

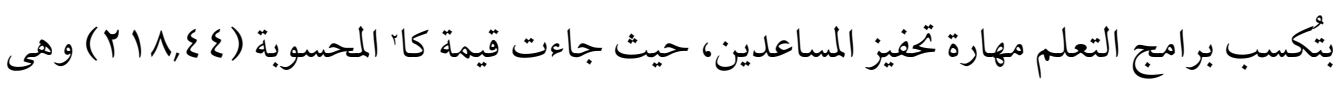

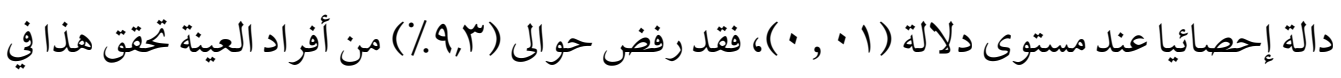
الو اقع الفعلي، بينما ترى نسبة (V, • ) منهم أنه يتحقق إلى حد ما، في حين أكد (•9\%) من أفراد العينة على تحقق هذا في الواقع الفعلي. وهذا مرجعه أن مهارة التحفيز لم تعد شيء ثانوي وانما أصبحت من اساسيات نجاح القائد في عمله، ومن ثم نجاح العمل . إلخ من فو ائد عديدة لهذه 
ـوجود فروق ذات دلالة إحصائية بين استجابات أفراد العينة نحو درجة تحقق العبارة الخاصة بـ تعمل برامج التعلم على تنمية مهارة تنسيق عمل المساعدين، حيث جاءت قيمة كان المحسوبة

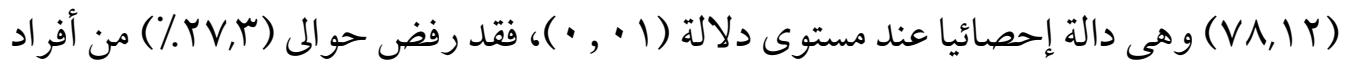
العينة تحقق هذا في الواقع الفعلي، بينما ترى نسبة (؟٪) منهم أنه يتحقق إلى حد ما، في حين أكد

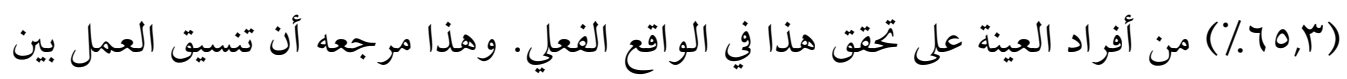

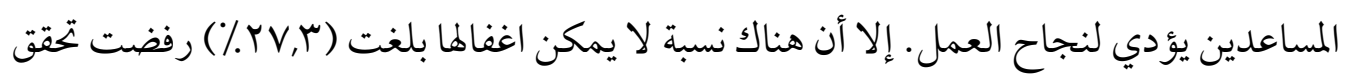
ذلك في الواقع، وهذا يحتاج إلى التركيز أكثر على هذه المهارة في برامج التعلم المقدمة لقيادات. ـ وجود فروق ذات دلالة إحصائية بين استجابات أفراد العينة نحو درجة تحقق العبارة الخاصة

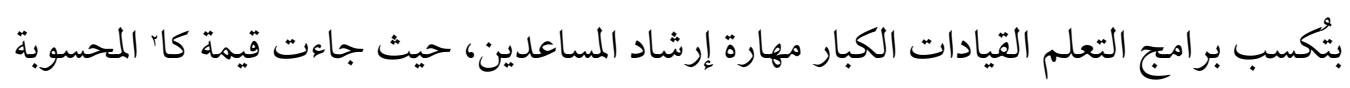

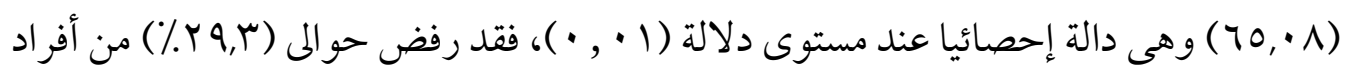

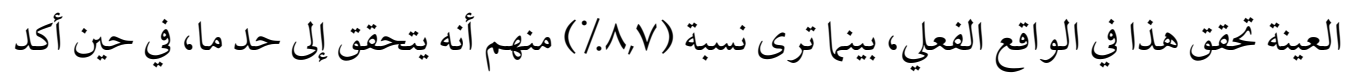

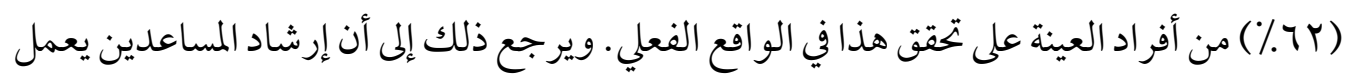

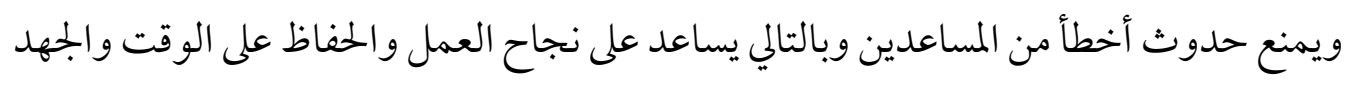

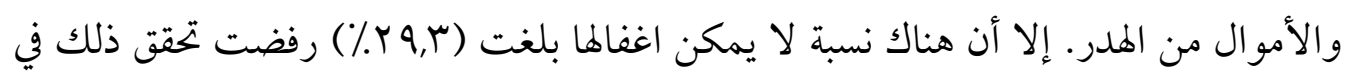
الواقع، وهذا يحتاج إلى إعادة النظر في برامج التعلم المقدمة للقيادات، بحيث تأخذ هذه المهارة المساحة المناسبة في هذه البرامج. - وجود فروق ذات دلالة إحصائية بين استجابات أفراد العينة نحو درجة تحقق العبارة الخاصة بيتم توظيف برامج التعلم في تنمية مهارة تطوير المساعدين، حيث جاءت قيمة كاء المحسوبة

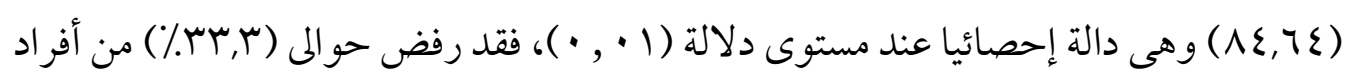

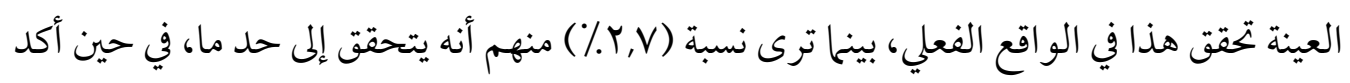


( آ7\%) من أفراد العينة على تحقق هذا في الواقع الفعلي. ويؤكد هذا على ضرورة الاهتحام ببرامج التعلم، حيث تمد القيادات بالمهارات اللازمة والتي منها تطوير المساعدين. إلا أن هناك نسبة لا يمكن اغفالها بلغت (r, سب/) رفضت تحقق ذلك في الواقع، وهذا يحتاج إلي زيادة التركيز على هذه المهارة ببرامج التعلم المقدمة للقيادات. - وجود فروق ذات دلالة إحصائية بين استجابات أفراد العينة نحو درجة تحقق العبارة الخاصة بـ تعمل برامج التعلم المستمر على تنمية مهارة تمكين المساعدين، حيث جاءت قيمة كان المحسوبة

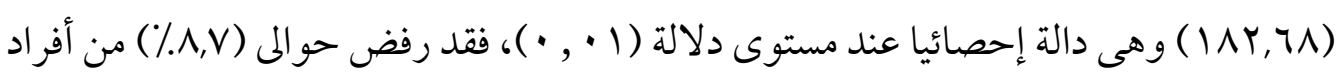

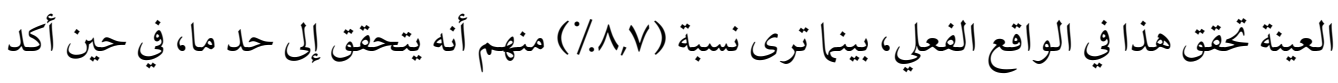
(ro,r\%) من أفر اد العينة على تحقق هذا في الواقع الفعلي. وربها يرجع هذا إلى أن تمكين المساعدين يعمل على زيادة قدرتهم على الإبداع، كما أن تمكين المساعدين يزيد من انتهاء الإنسان لعمله ويوفر له رضاو رظيفي. rـ إلى أي مدي توفر برامج التعلم المستمر مدي الحياة المهارات الفنية والتقنية للقيادات الكبار؟ جدول (^): دلالة الفروق بين استجابة أفراد العينة نحو مدى توفير برامج التعلم المستمر مدى الحياة المهارات الفنية والتقنية للكبار

\begin{tabular}{|c|c|c|c|c|c|c|c|c|}
\hline \multicolumn{7}{|c|}{ الاستحاة } & \multirow{3}{*}{ العبارات } & \multirow{3}{*}{$p$} \\
\hline \multirow[b]{2}{*}{ كاי } & \multicolumn{2}{|c|}{ لا } & \multicolumn{2}{|c|}{ إلى حد ما } & \multicolumn{2}{|c|}{ نعم } & & \\
\hline & $\%$ & s) & $\%$ & 5) & $\%$ & s) & & \\
\hline$* \wedge r, \cdot \wedge$ & $r 0, r$ & ror & $r^{\prime} \cdot$ & r & $T Y, V$ & $9 \varepsilon$ & تعمل برامج التعلم على تنمية & 1 \\
\hline$=179,97$ & IY, & 11 & $\varepsilon, V$ & V & r & Iro & تُكسب برامج التعلم مهارة تطوير & $r$ \\
\hline
\end{tabular}




\begin{tabular}{|c|c|c|c|c|c|c|c|c|}
\hline \multirow{3}{*}{ كاי } & \multicolumn{6}{|c|}{ الاستجابة } & \multirow{3}{*}{ العبارات } & \multirow{3}{*}{$\rho$} \\
\hline & \multicolumn{2}{|c|}{ لا } & \multicolumn{2}{|c|}{ إلى حد ما } & \multicolumn{2}{|c|}{ نعم } & & \\
\hline & $\%$ & 5) & $\%$ & 5) & $\%$ & 5) & & \\
\hline$* \| \wedge \Lambda, \varepsilon$ & $\varepsilon$, & 7 & $1 \cdot \cdot$ & 10 & $\wedge \uparrow$, & 179 & 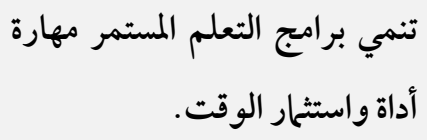 & $r$ \\
\hline$* \wedge 1,17$ & 17,1 & ro & $10, r$ & r & $\Upsilon \wedge$, & $1 \cdot r$ & 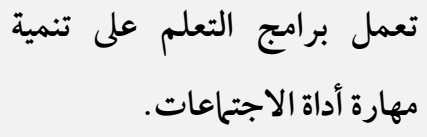 & $\varepsilon$ \\
\hline$*$ *YY, & $1, r$ & $r$ & $7, V$ & 1. & $9 r_{1} \cdot$ & IrN & تنمي برامج التعلم المستمر مهارة & ○ \\
\hline$*|Y| T$, & $\varepsilon 1, r$ & Tr & $r \cdot, \cdot$ & r. & $r \wedge, V$ & $0 \wedge$ & تُكسب برامج التعلم القيادات & 7 \\
\hline
\end{tabular}

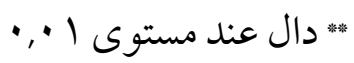

يتضح من الجدول السابق رقم (^) أن:

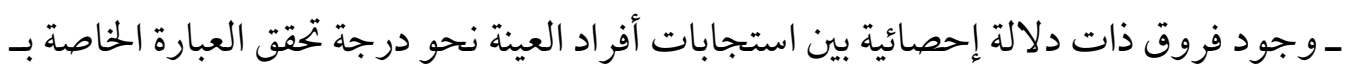
تعمل برامج التعلم على تنمية مهارة استخدام التكنولوجيا، حيث جاءت قيمة كان المحسوبة

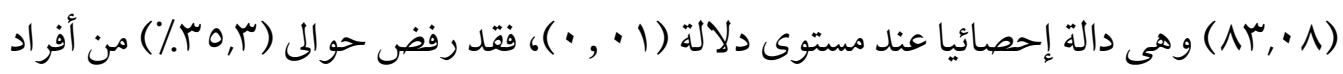
العينة تحقق هذا في الواقع الفعلي، بينما ترى نسبة (ז/\%) منهم أنه يتحقق إلى حد ما، في حين أكد دهد (\% من أفر اد العينة على تحقق هذا في الواقع الفعلي. وربها يرجع ذلك إلى أن التكنولوجيا

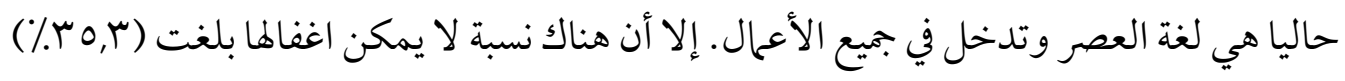
رفضت تحقق ذلك في الو اقع، وهو ما يجب أن يأخذ في الاعتبار من قبل المسئولين عن برامج التعلم المستمر عند تخطيطها وإعدادها. 
ـ وجود فروق ذات دلالة إحصائية بين استجابات أفراد العينة نحو درجة تحقق العبارة الخاصة بتُكسب برامج التعلم مهارة تطوير تقنيات العمل، حيث جاءت قيمة كاء المحسوبة (19,9 1 1 )

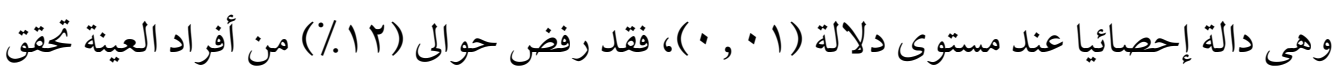

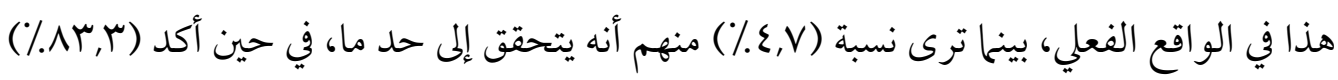

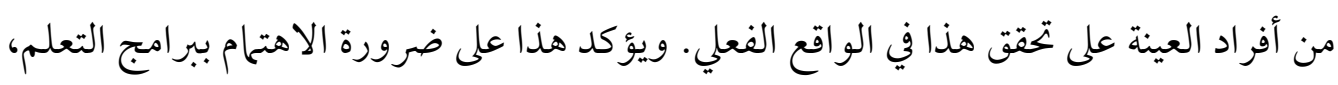
حيث تمد القيادات بالمهارات اللازمة ولتي تعمل على التطوير. ـوجود فروق ذات دلالة إحصائية بين استجابات أفراد العينة نحو درجة تحقق العبارة الخاصة بـ تنمي برامج التعلم المستمر مهارة إدارة واستثمار الوقت، حيث جاءت قيمة كان المحسوبة

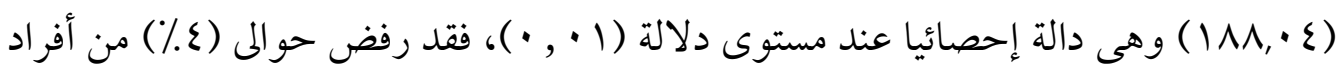

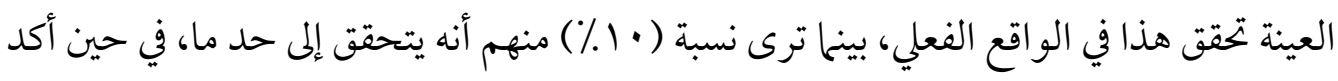

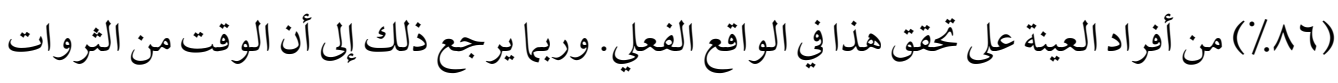

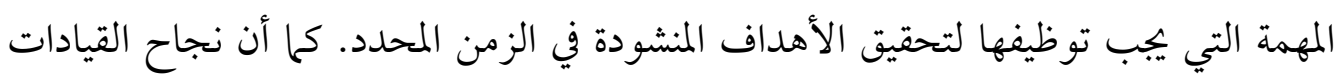
مرهون بحسن إدارة وقتهم ووقت العمل. ـ وجود فروق ذات دلالة إحصائية بين استجابات أفر اد العينة نحو درجة تحقق العبارة الخاصة بـ

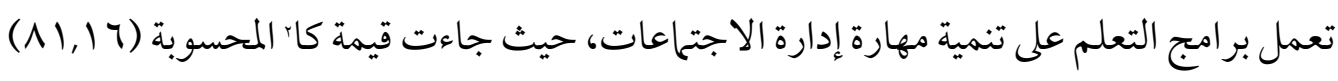

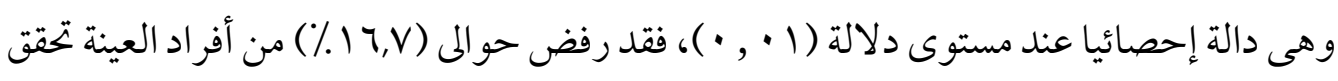

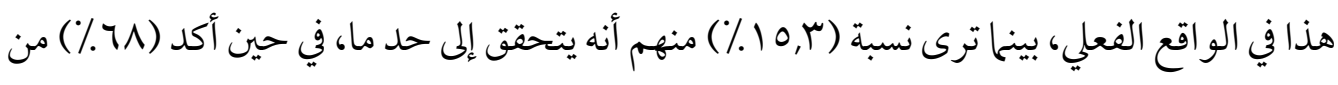

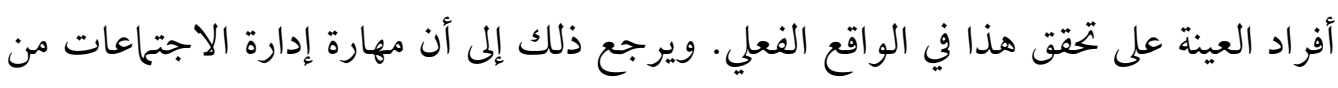

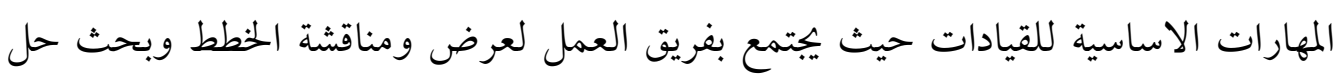
المشكلات والتحديات. إلخ ما يعمل على نجاح العمل. 
- وجود فروق ذات دلالة إحصائية بين استجابات أفراد العينة نحو درجة تحقق العبارة الخاصة بـ

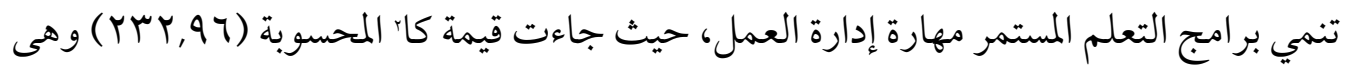

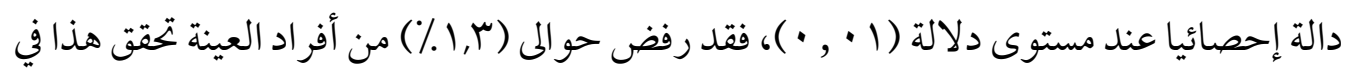

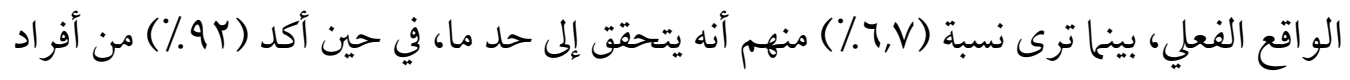

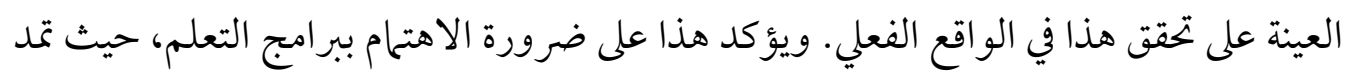
القيادات بالمهارات اللازمة ولتي تعمل على تنمية مهارة إدارة العمل لدي القيادات. - وجود فروق ذات دلالة إحصائية بين استجابات أفراد العينة نحو درجة تحقق العبارة الخاصة تـ

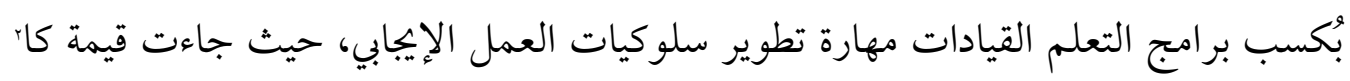

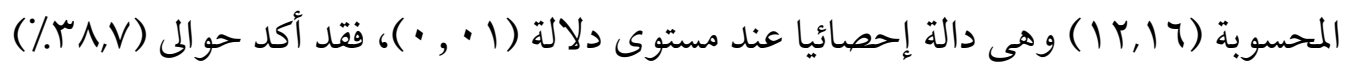

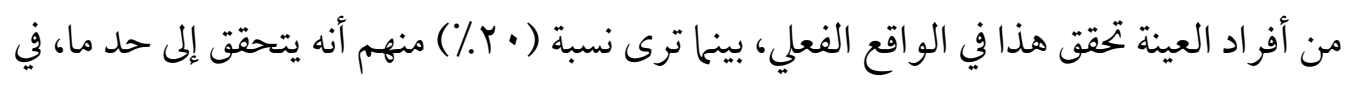

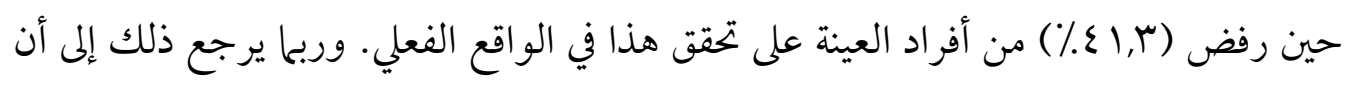

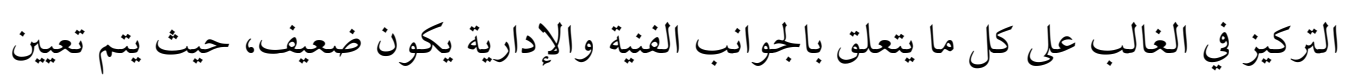

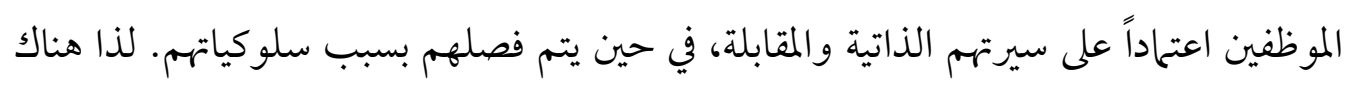

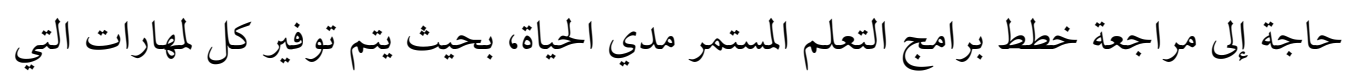
يحتاجها الكبار.

وبعد الوقوف على واقع برامج التعلم المستمر مدي الحياة في تنمية المهارات القيادية لدي الكبار، تسعى الدراسة في المحور التالي إلى وضع تصور مقترح لتنمية المهارات القيادية ببرامج

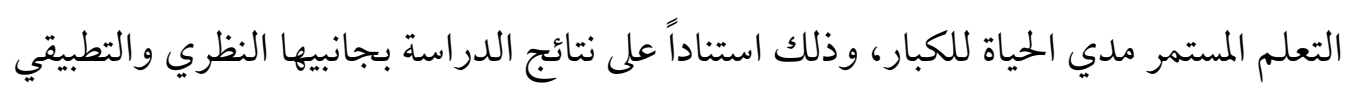
الميداني. 
المحور الرابع: تصور مقتزح لتنمية المهارات القيادية ببرامج التعلم المستمر مدي الحياة للكبار. أولاً: نتائج الدراسة.

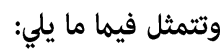

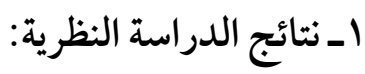
توصلت الدراسة للعديد من النتائج من خلال الإطار النظري ومن أهمها ما يلي: ـ تدني مستوي التعليم وتخريج نوعية من الطلاب لا تو اكب متطلبات العصر الحالي. ـ انخفاض مستوي التدريب، وبخاصة بالمؤسسات الحكومية. ـ أن المهارات التي يكتسبها الفرد من حلال برامج التعلم المستمر، تجعله يستطيع المنافسة في الاقتصاد العالمي، بل ويتمكن من العيش والحياة في هذا العصر سريع التغير. ـ تقل قيمة المهارات والمعارف التي يمتلكها الأفراد بسرعة، نتيجة التسارع الهائل للمعرفة وتكنولوجياتها.

ــ إن التعلم المستمر مدي الحياة يمثل " علامة أمان" للفرد وللبلدان. ـ التعلم المستمر مدى الحياة أصبح خياراً استراتيجياً نوعياً لا ينفصل إطلاقاً عن متطلبات النمو و التنمية و التحديث لخلق تنمية مستدامة. ـ أن التعليم النظامي بكافة مر احله ماز ال يعاني من بعض السلبيات مثل: قلة الوسائل التي تساعد على تنمية مهارات التعلم، مما يضعف من قدرته على المنافسة داخلياً وخارجياً. ـ إن التغير المستمر في متطلبات سوق العمل المتغيرة يفرض على الإنسان التجديد لمهارته لتو اكب الجديد والمتجدد من المهارات المطلوبة في سوق العمل العالمي الواسع والمحلي. ـو هناك حاجة إلى التركيز على التعلم المستمر مدي الحياة باعتباره يعمل باستمر ار على بناء المهارات والمعارف طو ال حياة الفرد.

ـ يساعد التعلم المستمر مدي الحياة الافر اد على اتخاذ القرار الاحسن، وينمي مهاراتهم في حل المشكلات التي تو اجهطم في بيئة العمل. 
ـ أن أهداف التعلم المستمر مدي الحياة لا تعتبر أهداف نهائية، بل هي أهداف تتجدد وتتغير وفقاً لتجدد وتغير تطلعات الانسان وقدر اته وظروفه المحيطة ـ أن إيجاد القيادة الإدارية السليمة، والقادرة على مو اجهة المستجدات العصرية مرتبط بتوفير برامج تعلم تعمل على تنمية المهارات القيادية ـ أن نمو وتقدم المجتمعات إنسانياً وحضارياً وتكنلوجياً ومهنياً - بمنظلاته ومؤسساته ومرافقه المختلفة مرتبط إلى حد كبير بفاعلية قياداتها.

ـ هناك ضرورة ملحة لبحث توفير بيئة قيادية مشجعة وحفزة تتو اكب مع المتغيرات المستمرة. ـ تعدد وتتنوع تحديات القرن الحادي و العشرين من كوارث طبيعية وأزمات تنظيمية وصراعات بشرية تلقي بعبئها على المنظلات والمؤسسات، بالإضافة إلى ارتفاع سقف توقعات المستفيدين من

الخدمات المقدمة من هذه المؤسسات كل هذا يستدعي تطوير القيادات وتنميتها باستمرار. ـ القيادة هي المسئول الأول لدعم القوي الإيجابية في المؤسسة وتقليص الجوانب السلبية. ـ تعمل القيادة على السيطرة على مشكلات العمل وحلها، وحسم الخلافات و الترجيح بين الآراء، وتنمية وتدريب ورعاية الأفر اد باعتبارهم أهم مورد في للمؤسسة. ـ تمثل المهار ات أحد المطالب الرئيسة للقيادات، حيث تعمل على تقدم وتفوق المؤسسات والأفراد ليس هذا فقط، بل ومصدر لتحقيق نجاحها في تحقيق الأهداف المنشودة.

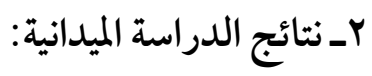
توصلت الدراسة للعديد من النتائج من خلال الدراسة الميدانية ومن أهمها ما يلي: ـ أظهرت النتائج المرتبطة بواقع دور ببرامج التعلم المستمر مدي الحياة في تنمية المهارات القيادية لدي الكبار أنه تحقق كل من: الأهداف المنشودة للبرامج، ويتم التنسيق بين كافة المشاركين في وضع البرامج لمنع تكرارها، وتعمل برامج التعلم المستمر على زيادة أداء القيادات في الميدان، 
ويراعي في برامج التعلم المقدمة للقيادات خطط التنمية الوطنية، ويوجد رقابة على برامج تعلم

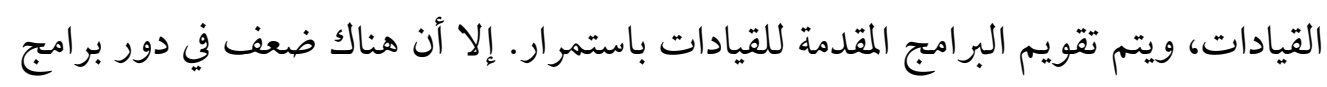

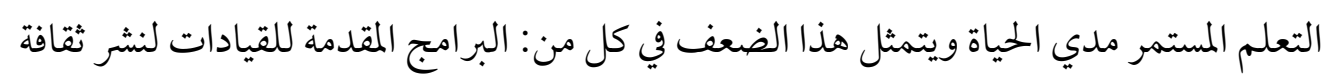

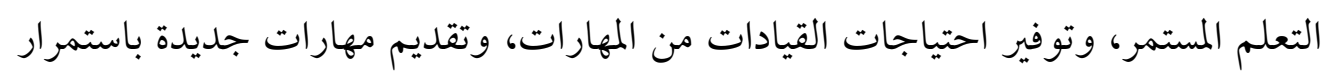
للقيادات، وتقديم تغذية راجعة بعد الانتهاء من تقويم برامج التعلم المستمر. - و وأظهرت النتائج المرتبطة بمدي توفر برامج التعلم المستمر مدي الحياة المهارات الفكرية

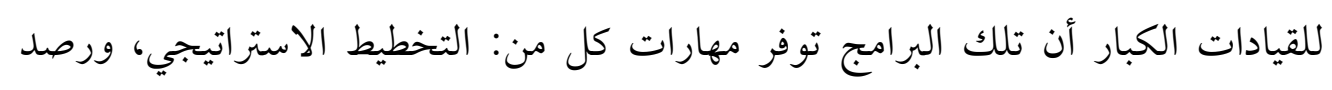

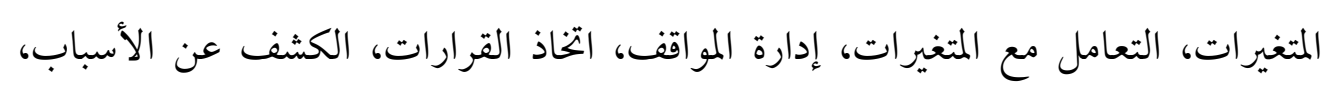

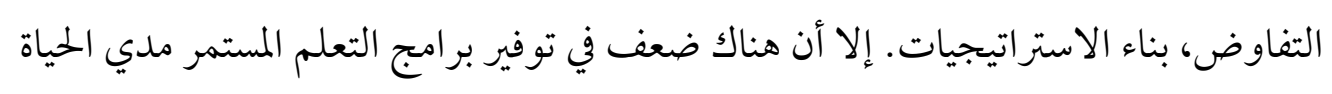
ببعض المهارات الفكرية مثل حل المشكلات، واستقراء المؤشرات، وإدارة المعلومات.

ـ وفيها يتعلق بمدي توفر برامج التعلم المستمر مدي الحياة المهارات الإنسانية للقيادات الكبار تبين

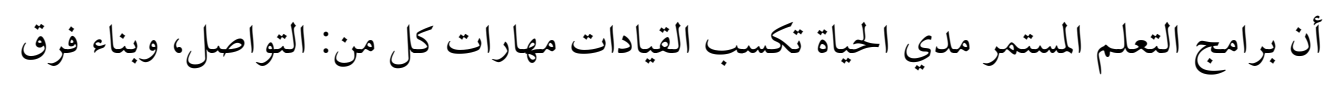

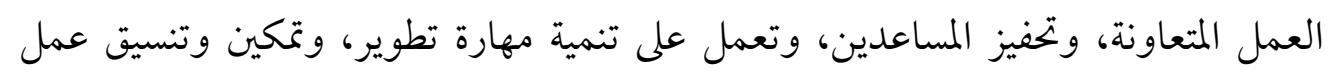

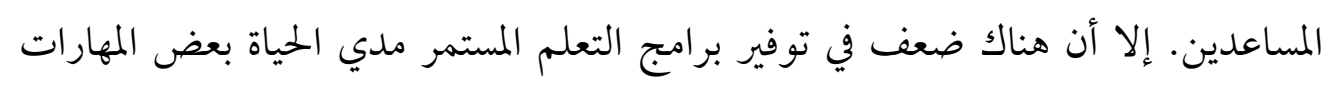
الإنسانية مثل مهارتي اختيار وإرشاد المساعدين.

ـ و أظهرت النتائج المرتبطة بمدي توفر برامج التعلم المستمر مدي الحياة المهارات الفنية والتقنية للقيادات الكبار أن تلك البرامج توفر مهارات كل من: استخدام التكنولوجيا، وتطوير تقنيات

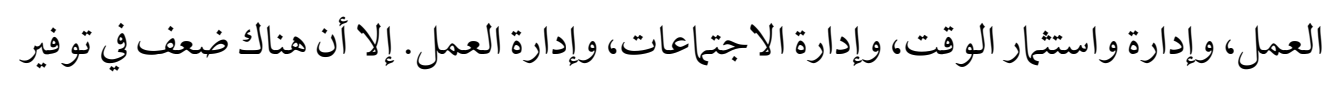
برامج التعلم المستمر مدي الحياة ببعض المهارات الفنية للقيادات مثل مهارة تطوير سلوكيات العمل الإيجابي. 
ثانياً: التصور المقترح لتنمية الههارات القيادية ببرامج التعلم المستمر مدي الحياة للكبار.

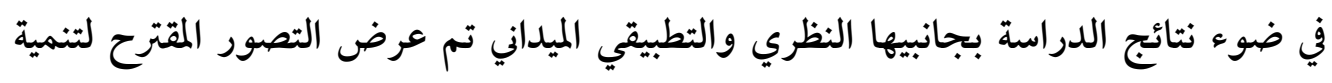
المهارات القيادية لدي الكبار ببرامج التعلم المستمر مدي الحياة فيها يلي: ـ ـ ملسفة التصور المقترح: تنطلق فلسفة التصور المقترح من حقيقة، أن الاهتحام بتنمية المهارات القيادية ببرامج التعلم المستمر مدي الحياة للكبار وتوفير احتياجاتهم من هذه المهارات أصبح خياراً استراتيجياً نوعياً لا ينفصل إطلاقاً عن متطلبات النمو والتنمية والتحديث؛ لخلق تنمية مستدامة، وهذا يتطلب تطوير المهارات القيادية ببرامج التعلم المستمر، بها يتماشى مع احتياجات القادة ومع المتغيرات المستمرة، وكل هذا مرهون بتطوير برامج التعلم المستمر مدي الحياة. rـ أسس ومنطلقات التصور المقترح: يقوم التصور المقترح على العديد من الأسس والمرتكزات من أهمها ما يلي: ا ـ تم الاطلاع على الدراسات والبحوث والأدبيات المرتبطة بتنمية المهارات القيادية لدي الكبار ببرامج التعلم المستمر مدي الحياة. والتي تم تناول البعض منها بالدراسة الحالية. זـ الواقع الراهن لتنمية المهارات القيادية لدي الكبار ببرامج التعلم المستمر مدي الحياة، وقد تم تناولها بالدراسة من الجانبين النظري، والتطبيقي من خلال الدراسة الميدانية؛ وذلك بهدف التعرف على كل من النتائج الإيجابية و السلبية التي تواجه بر امج التعلم المستمر مدي الحياة الخاصة بتنمية المهار ات القيادية لدي الكبار.

بـ أن المهارات هي المفتاح لازدهار الأمم، بل وتعمل على توفير حياة أفضل للأفراد في القرن الحادي والعشرين. لذا دائحاً هناك حاجة لصقل وتحديث مهارات القيادات باستمرار. 
أهداف التصور المقترح: في ضوء كل من الفلسفة التي ينطلق منها التصور المقترح، والأسس التي يرتكز عليها تم تحديد

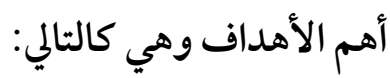
ـ دعم فكرة التعلم المستمر مدي الحياة ليكون أسلوب حياة لدي القيادات. ـ تطوير برامج التعلم المستمر مدي الحياة، لتوفير احتياجات القيادات الكبار من المهارات. ـ تمكين القيادات من التعلم المستمر مدي الحياة، لتنمية مهارتهم؛ لمو اكبة المتغيرات العصرية. ـ توجيه السادة متخذي القرار والمسئولين عن ببرامج التعلم المستمر مدي الحياة إلي زيادة الاهتحام بتلك البرامج، وتوفير كل ما يعمل على تنمية مهار ات القيادات الكبار باستمرار. إجر اءات وآليات التنفيذ:

اـ أن تعمل البرامج المقدمة للقيادات على نشر ثقافة التعلم المستمر مدي الحياة. r- دراسة احتياجات القيادات من المهارات، لوضعها في الاعتبار عند تصميم برامج التعلم المستمر مدي الحياة؛ بحيث تلبي احتياجات القيادات من المهارات. مـ مراعاة خطط التنمية الوطنية عند وضع برامج التعلم. عـ التنسيق بين كافة المشاركين في وضع البرامج لمنع تكرارها، والتأكد من تجديدها وتحديثا باستمرار، لتو اكب المتغيرات والمستجدات.

0ـ أن تتنوع المهار ات المقدمة للقيادات، بحيث تشمل كل من المهارات الفكرية والإنسانية والفنية و التقنية.

7ـ أن يتم تقويم برامج التعلم المستمر المقدمة للقيادات باستمرار، للتأكد من أنها تحقق الأهداف المنشودة، وتعمل على زيادة أداء القيادات في الميدان. V_ تقديم تغذية راجعة بعد الانتهاء من تقويم برامج التعلم المستمر. 
^ــ أن يكون هناك رقابة ومتابعة مستمر لبرامج التعلم المستمر مدي الحياة المقدمة للقيادات، على أن يتبع ذلك المحاسبة والمساءلة للمقصرين والقائمين أو المسئولين عن تلك البرامج، وتحفيز أو تقديم مكافئة للمتقنين لعملهم و المتميزين، وذلك لضبط العمل. 9ـ الاستفادة من خبرات بعض الدول ومؤسسات و أكاديميات ومراكز التدريب التي حققت طفرة في مجال برامج التعلم المستمر مدي الحياة؛ لتطوير تلك البرامج. ثانياً: أن تلبي برامج التعلم المستمر مدي الحياة احتياجات القيادات من المهارات: إجر اءات و آليات التنفيذ: أن تتضمن برامج التعلم المستمر مدي الحياة المقدمة للقيادات الكبار المهارات التالية:

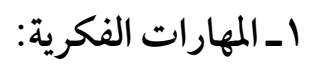

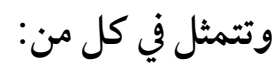
ـ مهارة بناء الاستراتيجيات وتنمية السياسات. ـ مهارة التخطيط الاستراتيجي و القدرة على اتخاذ القرار. ـ مهارة الاستنتاج واستقر اء المؤشرات. ـ مهارة تحليل المشكلات و الكشف عن الأسباب. ـ مهارة إدارة المو اقف وروصد المتغيرات. ـ مهارة إدارة المعلومات و التعامل مع المتغيرات.

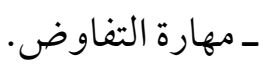

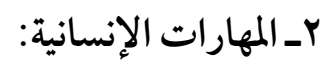

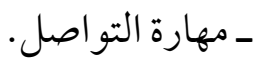
ـ مهارة اختيار المساعدين. 
ـ مهارة ارشاد المساعدين. ـ مهارة تطوير المساعدين. ـ مهارة تمكين المساعدين. ـ مهارة تنمية المساعدين. ـ مهارة بناء فرق العمل المتعاونة. ـ مهارة تحفيز وتشجيع المساعدين.

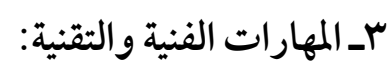

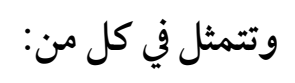

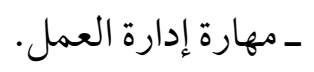
ـ مهارة استخدام التكنولوجيا وتقنية المعلو مات.

$$
\text { ـ ـ مهارة تطوير تقنيات العمل. }
$$

كل هذه المهار ات تتفاعل وتتداخل فيها بينها لتشكل كلاً متكاملاً من المهارات التي يجب اكسابها للقيادات مع الاشارة إلى أن كلها مهارات مهمة ولا تقل إحداهما عن البقية، كما أن جميع هذه المهارات تصلح لوضعها ببرامج التعلم المستمر ومن ثم قابلة للتعلم والاكتساب. 
ثالثاً: أن تتضمن برامج التعلم المستمر مدي الحياة بعض السمات والصفات القيادية كمكملة

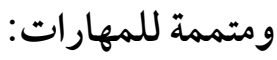

$$
\text { إجر اءات و آليات التنفيذ: }
$$

إن الاهتحام بالمهارات لإكسابها للقيادات لا يجعل الدراسة تتجاهل السمات أو الصفات الشخصية للقيادات؛ لما لها من أثر بالغ الأهمية في العملية القيادية ونجاحها، ومن أهم سمات و صفات القائد الناجح ما يلي:

$$
\text { بـ ـ ـ العدل. النزاهة. }
$$

عـ الاستعداد للعمل بجد.

○ـ القدرة على التحليل.

$$
\text { 7ـ فهم الآخرين. }
$$

V_ القدرة على تحديد الفرص.

^ـ القدرة عللي مو اجهة المو اقف السيئة.

9ـ القدرة على التأقلم بسرعة مع التغيير.

• ـ ـ الاستعداد لتحمل المخاطر.

$$
\text { 11 - إلمغامرة. }
$$

r ا ـ القدرة على التحدث بوضوح.

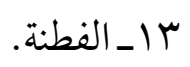

ع ا ـ القدرة على الإدارة بكفاءة. 


$$
\begin{aligned}
& \text { ا ـ ـ تفتح العقل. } \\
& 7 \text { ـ ـ القدرة على "المثابرة". } \\
& \text { I ا ـ الاستعداد للعمل لساعات طويلة. }
\end{aligned}
$$

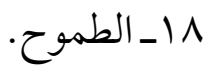

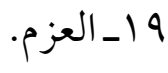

$$
\begin{aligned}
& \text { • · ـ القدرة على الكتابة بوضوح. }
\end{aligned}
$$

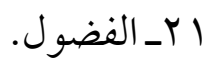

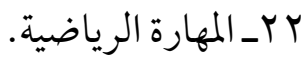

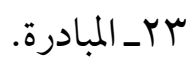

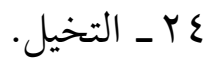

$$
\begin{aligned}
& \text { O _ التضحية، يضحي برغباته واحتياجاته من أجل الصالح العام. }
\end{aligned}
$$

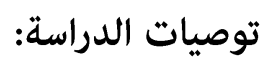

في إطار ما تم تناوله في الدراسة، وفي إطار التصور المقترح يمكن الخروج بعدة توصيات وهي كالتالي:

ـ نشر ثقافة التعلم المستمر مدي الحياة بكافة الوسائل والمواقع الإليكترونية، حتى يصبح أسلوب حياة عند القيادات بخاصة والمجتمع عامة.

ـ قيام الجاهات المسئولة عن برامج التعلم المستمر مدي الحياة ببناء برامج تعلم متكاملة تتضمن كافة احتياجات القيادات من المهارات، واكسابها لهم. 
ـ العمل المستمر على تطوير وتحديث برامج التعلم المستمر وما تتضمنه من مهارات ومعارف

$$
\text { وغير هما؛ حتى لا يجدث تكرار. }
$$

ـ تمكين القيادات من التعلم المستمر، وتوفير بيئة تعلم مناسبة ومشجعة على استمرار القيادات في التعلم مدي الحياة.

- إصدار تشريع يلزم كل من يريد أن يتولى مهمة قيادية، أن يكون مكتسب لمجموعة المهارات السابق ذكرها، ويتصف ويتحلى بالسمات سالفة الذكر. 


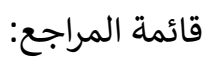

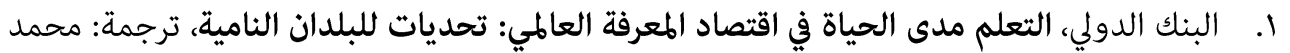

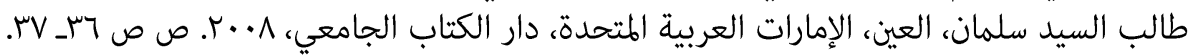

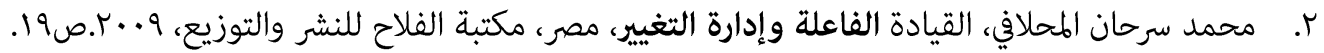

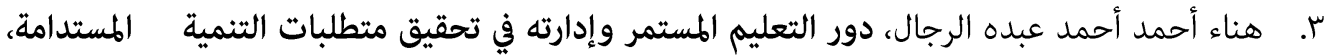

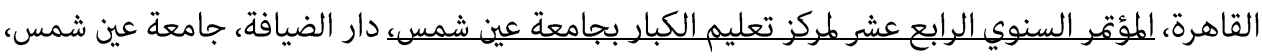

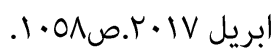

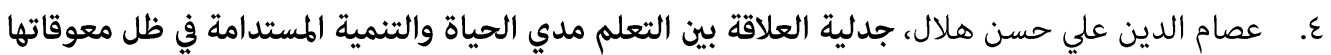

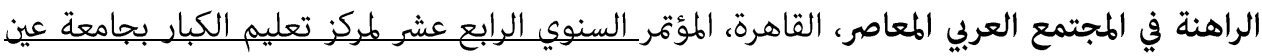

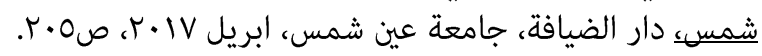

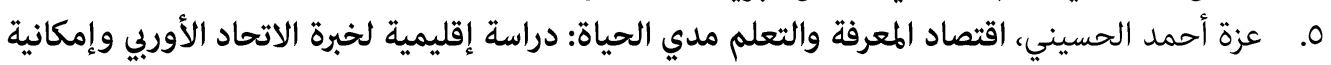

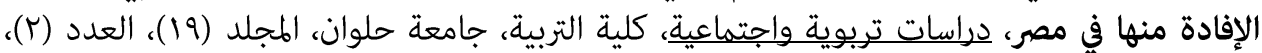

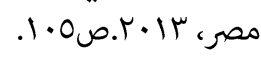

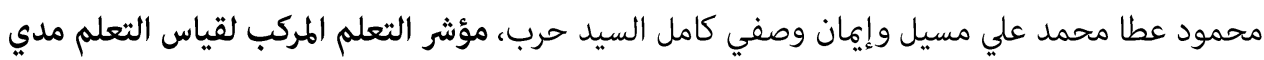

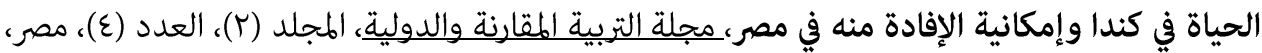
r. 17 V. بلقيس عبد الوهاب عبد الله، التعلم مدي الحياة برامجه وآليات تنفيذه، مترجم/ مركز البحوث

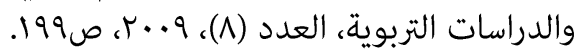

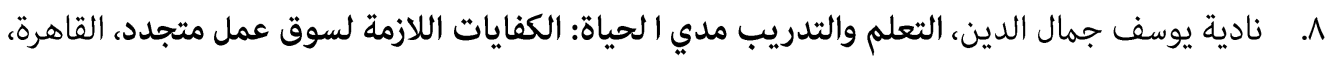

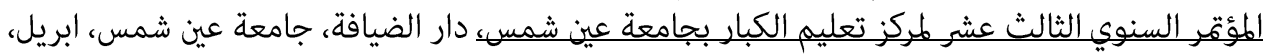

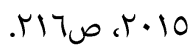

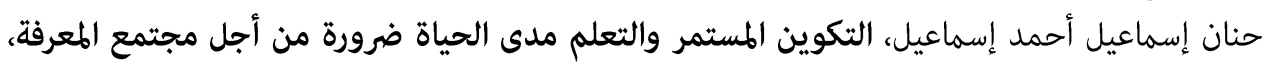

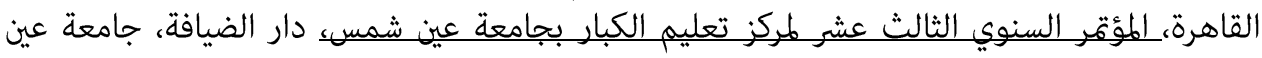

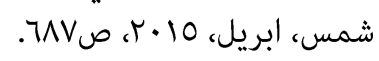

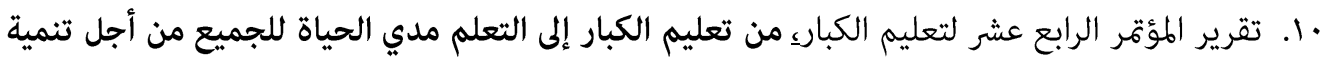

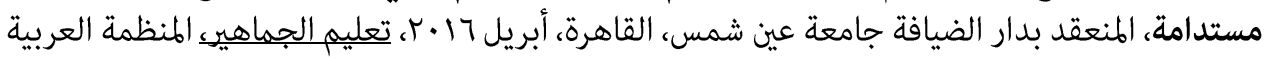

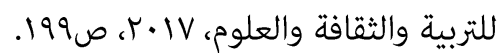

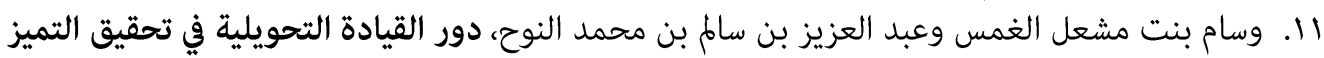

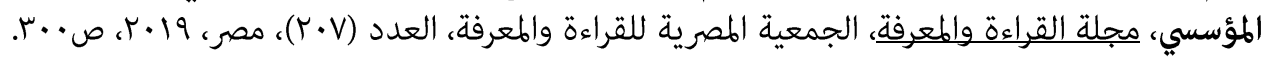

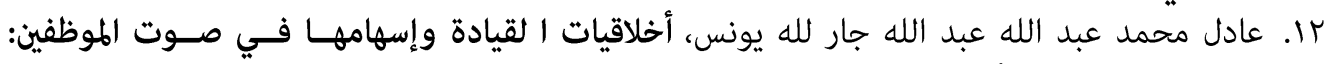

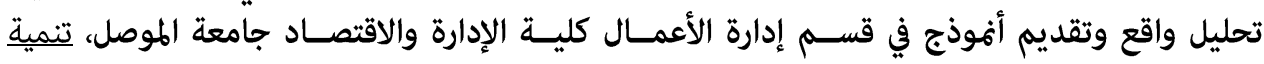

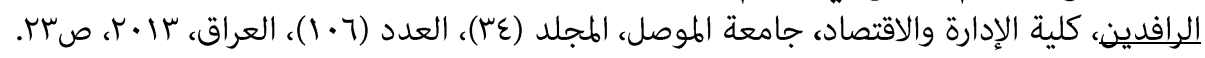

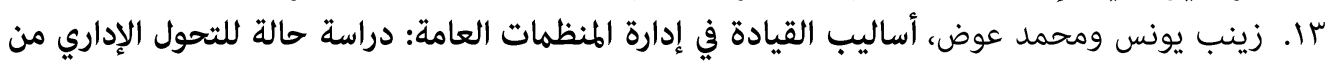

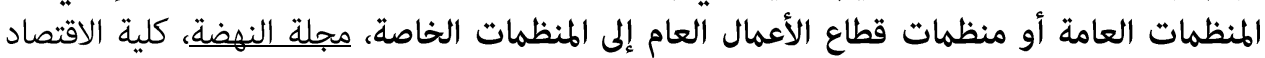

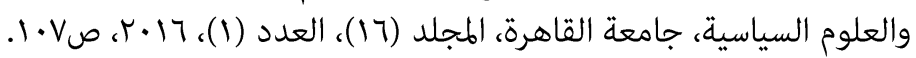


عا. عابد بن عبد الله العصيمي، استراتيجية تطوير القيادة الإدارية في الأجهزة الحكومية، المجلة العربية

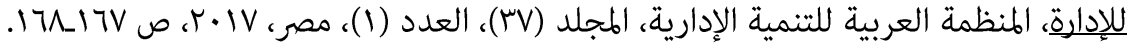

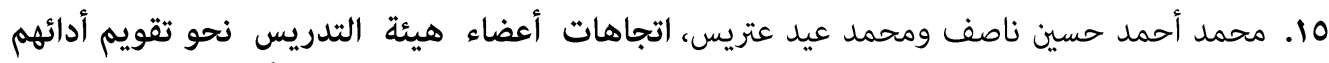

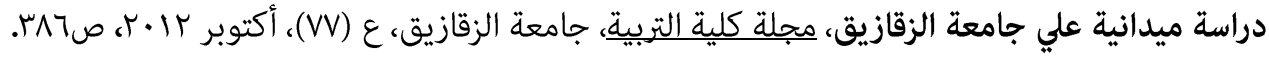

16. Jarvis, Pete, International Dictionary of Adult and Continuing Education, London, Kogan Page Limited, 1999, P.160.

17. Kuper, Adm \&) Kuper Jessica, The Social Science Encyclopedia, 2nd. Ed. London, Routledge Press, 1996, P.749.

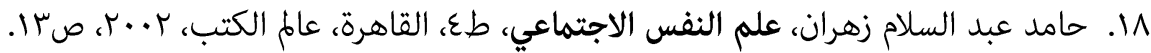

19. The Collins English Dictionary: Lifelong Learning - Definitions, 2015, available at: http://www.collinsdictionary. Com. On (8- 1- 2019).

• r. أسامة محمود فراج، التعليم والتعلم المستمر وقضايا الألفية الثالثة، القاهرة، المليجي للنشر والخدمات

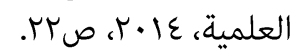

21. Bhandar, Rajika, Rural Women in India: Asseessment of Educational Constraints and the Need for New Educational Approaches. North Carolina State University. Journal f Research in Rural Education, Vo1.13, 2009, PP.183-196.

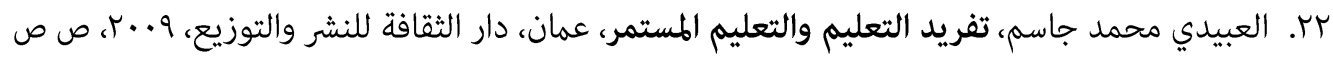
ع ع r

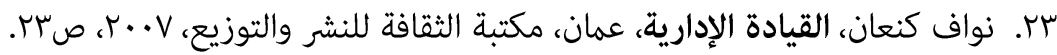

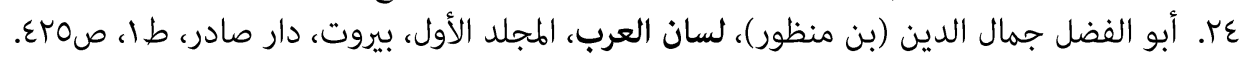

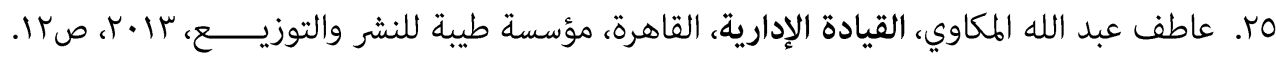

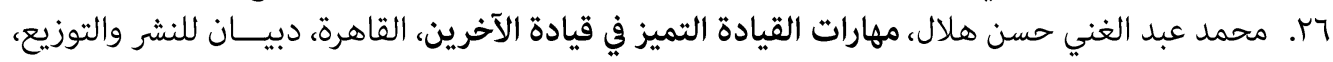
. 9.11

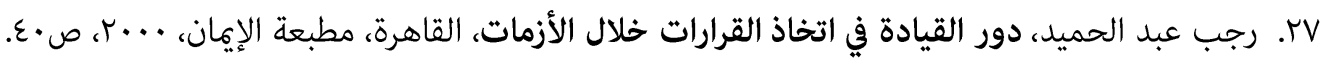

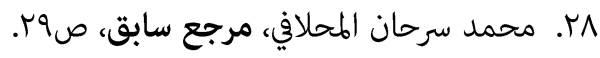
29. Yukl,Gary, Ledership in organizations.USA, prentice-Hall, Inc, 2002, P.7.

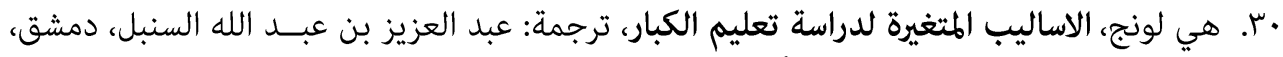

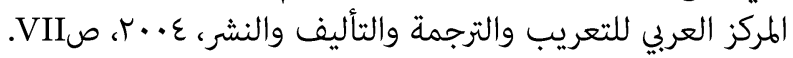

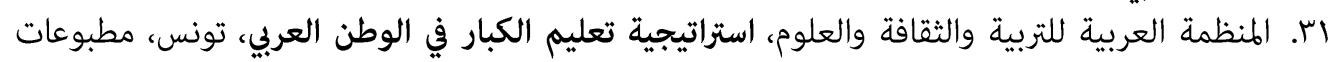

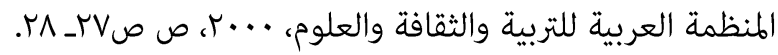

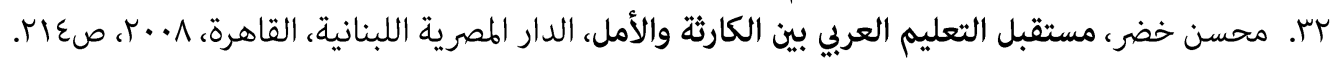

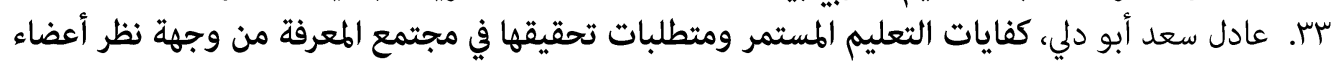

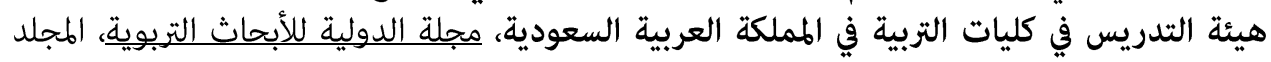
(r)

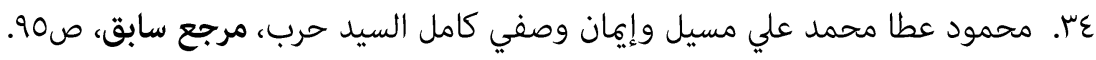


35. Henre Murray, Lifelong Learning in the Twenty- First Century: An Investigation of the Interrelationships Between Self Directed Learnng and Lifelong, Ed.D., Union Institute\& University, Cincinnati,hio, 2015.

$$
\text { 7س. وسام بنت مشعل الغمس وعبد العزيز بن سالم بن محمد النوح، مرجع سابق. }
$$

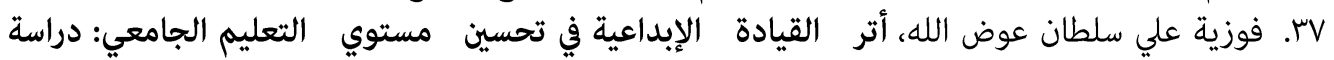

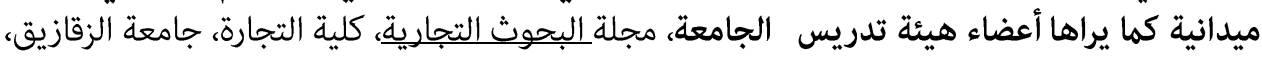

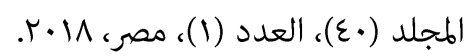

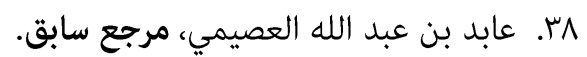
وس. فاروق جعفر عبد الحكيم مرزوق، جودة برامج التعلم المستمر: تصور مقترح، القاهرة، المؤَّر الدولي

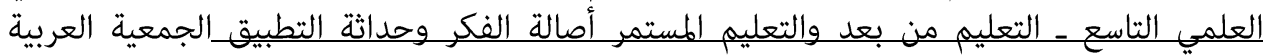

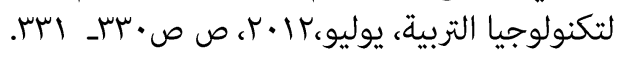

40. Terry Clar, Lifelong Life - Wid or Life Sentence, Australin Journal of Learning, Vo1.45, No.1,April, 2005. P.48.

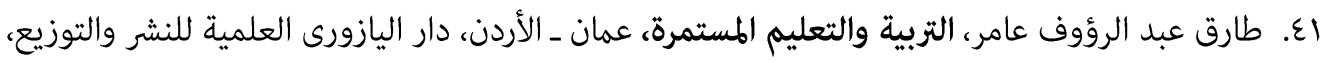

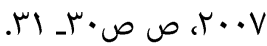

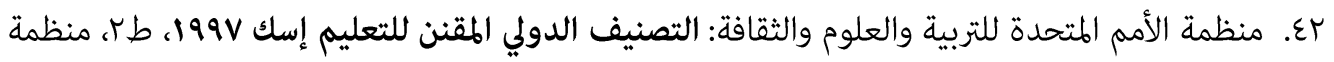

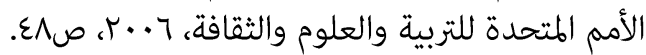

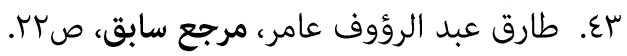

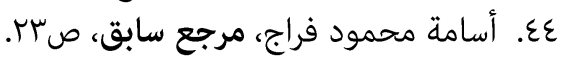

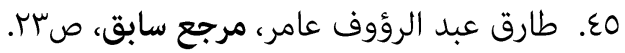

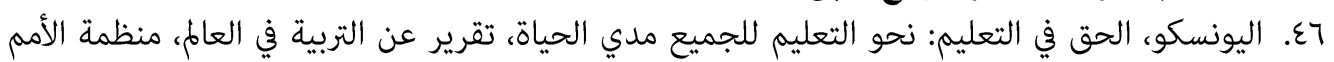

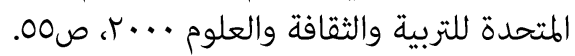

VV V. أحمد إسماعيل حجي، التربية المستمرة والتعلة والتعلم مدي الحياة: للتعليم غير النظامي وتعليم الكبار

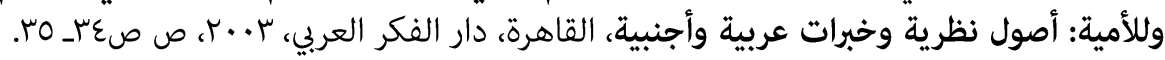

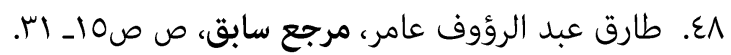

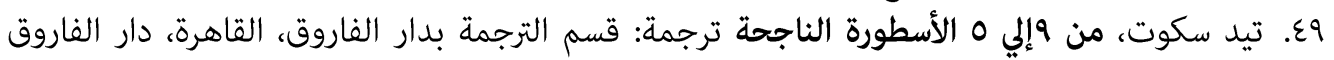

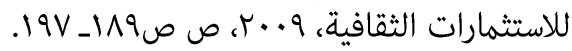

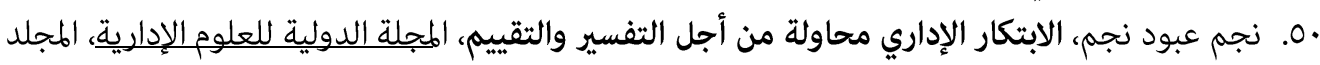

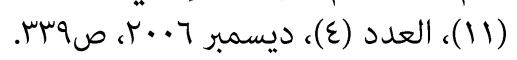
ا ه. محمد الطعامنة وطارق شريف يونس، الإبداع، مقوماته، ومعوقاته، ودراسة لآراء عينة القيادات الإدارية

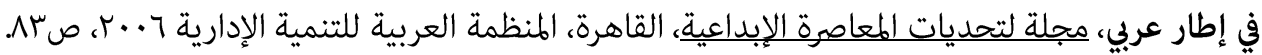

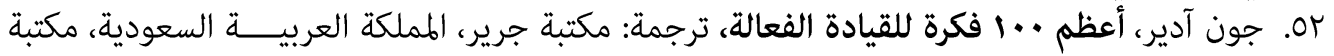

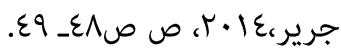

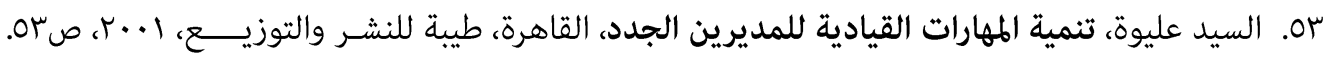

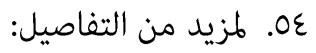

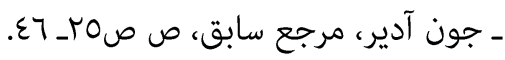


ـ السيد رجب السيد عيد، المهارات الإدارية في القيادة وأثارها في مكافحة الفساد، ورشة عمل: تنمية المهارات

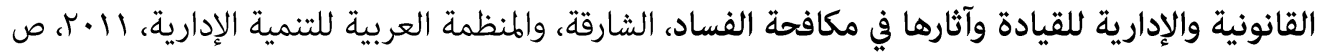

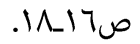

ـ نجم عبود نجم، مرجع سابق، صوr.

- Le negrad - assayag emmanulle, mancean Delphine, marketing des nouveaux produits paris, 2005, P.21. 